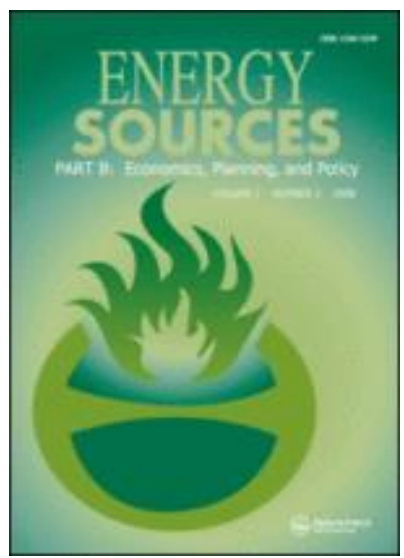

Power sector asset stranding effects of climate policies

\begin{tabular}{|r|l|}
\hline Journal: & Energy Sources, Part B: Economics, Planning, and Policy \\
\hline Manuscript ID & UESB-2019-0020.R2 \\
\hline Manuscript Type: & Original Papers \\
\hline Keywords: & $\begin{array}{l}\text { electricity generation capacity, power sector, fossil fuels, renewable } \\
\text { energy, stranded assets, decarbonization }\end{array}$ \\
\hline
\end{tabular}

SCHOLARONE ${ }^{m}$

Manuscripts 


\title{
Power sector asset stranding effects of climate policies
}

\author{
Word count: 7,933-950 words (excluding footnotes, abstract, tables, figures, \\ acknowledgements, references and appendices)
}

\begin{abstract}
Energy sector decarbonization to limit the temperature rise to well-below 2 degrees Celsius will result in stranded assets and capital stock replacement before its technical lifetime ends. In this paper, stranded assets in the global power sector are quantified based on a simplified bottom-up analysis that considers the capital stock turnover of fossil fuel-fired power plants in the G20 countries between 2015 and 2050. Power sector transformation starting now based on accelerated deployment of renewables results in US dollar (USD) 927 billion of global power sector stranded assets by 2050 . Stranded coal assets would represent around three-quarters of total stranded assets value and China alone would represent $45 \%$ of the total. Delaying action to mitigate climate change until 2030 doubles stranded asset value. Countries should consider assets' age profile characteristics in their decision making. Early action and avoidance of investments in new carbon-intensive assets can minimize stranded asset risks.
\end{abstract}

Keywords: electricity generation capacity; power sector; fossil fuels; renewable energy; stranded assets; decarbonization

\subsection{Introduction}


Energy sector greenhouse gas emissions reduction for effective climate change mitigation requires a global energy transition. Renewable energy and energy efficiency will play a key role

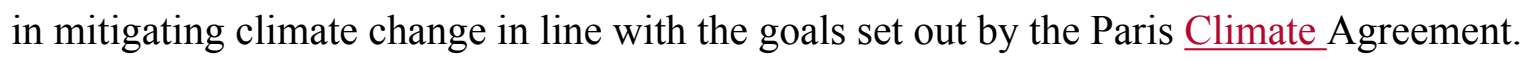
Renewable energy and energy efficiency technologies together can achieve up to $90 \%$ of the required carbon dioxide $\left(\mathrm{CO}_{2}\right)$ emissions reductions in the energy sector by 2050 (IRENA and IEA, 2017). The power sector must play a particularly important role as it is by far the largest $\mathrm{CO}_{2}$ emitting sector that accounts for more than $40 \%$ of all $\mathrm{CO}_{2}$ emissions from fossil fuel combustion (IEA, 2017).

In 2017 , total installed electricity generation capacity worldwide reached 6,801 gigawatts (GW). Fossil fuel and nuclear capacity represents $66 \%$ of this with a total installed capacity of 4,622 GW. The remaining $34 \%$ is renewables $(2,179 \mathrm{GW})$, mainly from hydropower $(1,271 \mathrm{GW})$ (IRENA, 2018; IEA, 2018a). The share of renewables in total installed generation capacity is increasing on average by $1.4 \%$ per year. Since 2012 , renewables have accounted for more than half of global electricity generation capacity additions, notably hydropower, solar PV and wind (IEA, 2018a; IRENA, 2017a; FS-UNEP, 2017). Currently around a quarter of all electricity is generated from renewables and this share continues to rise from year to year.

The share of renewable power electricity generation must increase further, and renewables must account for the majority of most power electricity generation between now and 2050. Such a transition in the capacity mix would imply changes in power sector's investments-generation eapacity. Such These changes have important implications for a wide range of stakeholders, including investors, companies and policy makers ( $\mathrm{Zhao}$ and $\mathrm{Du}, 2017$; Karakosta, Flamos and 
Forouli, 2018; Nikas et al., 2018). The issue concerning the fossil fuel sector has been highlighted by Mark Carney, Governor of the Bank of England and Chair of the Group of Twenty (G20) Financial Stability Board with the term "stranded assets" and he has requested an evaluation of its risks and potential magnitude (Carney, 2015; Edenhofer et al., 2017). Later in the year 2017, the German Presidency of the G20 has recognized the importance of developing strategies to minimize the devaluation of assets in the energy sector $(G 20,2017)$. This was a particularly important step since the G20 brings together the world's largest and emerging economies and it can play a crucial role for the promotion of global energy markets.

To date, much of the existing research has focused on asset stranding facing listed upstream fossil fuel producers, particularly international oil companies listed on the New York and London stock exchanges, and how their fossil fuel reserves are incompatible with required carbon budgets (see Table 1). ${ }^{1}$ This upstream focus potentially misses an important part of the impacts. In a transition to a low-carbon energy sector, sectors such as electricity generation are

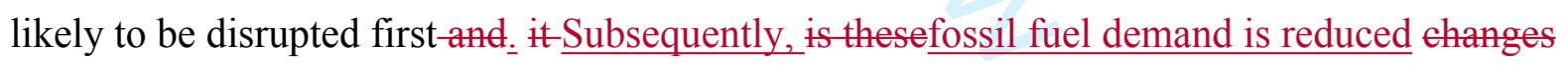
which athat then affects the value of fossil fuel production assets by reducing demand for fossit fuel assets. Delaying action could potentially result in a higher stranded asset value as it requires accelerated efforts to meet the same policy goal (Bertram et al., 2015).

Analysis of existing studies on asset stranding in the global power sector suggests that important knowledge gaps remain (see section 2). Availability of country-level estimates for the power

\footnotetext{
${ }^{1}$ Carbon budget is defined as the maximum level of $\mathrm{CO}_{2}$ that can be emitted to remain below a certain temperature with a probability value.
} 
sector and for power plants beyond coal-fired assets are limited. Also ilt is necessary to expand the technology scope to gas-fired power plant capacity which is growing rapidly worldwide. In $\underline{\text { several-addition countries, }}$, oil-fired power plants are still an import part of the capacity mix in several countries. In addition, future new power plants beyond those in operation and already commissioned ones are also subject to risk of being stranded and their impact on total stranded assets need to be understood. This is particularly the case for countries with rapid growth in electricity demand where new capacity will be needed in the future. Furthermore, most available studies estimate the stranded asset value either in physical or economic terms, but not in both. Finally, there are no estimates that pertain to the most recent carbon budgets published by the Intergovernmental Panel on Climate Change (IPCC) that are in line with meeting the Paris Climate Agreement goals (Rogelj et al., 2018). In view of these knowledge gaps, we set the main objective of this paper to undertake an analysis of asset stranding in the global power sector and estimate its physical (in GW) and economic (in USD) value for the 2015-2050 period by paying attention to when climate policy action is taken. We set the boundaries to cover all types of fossil fuel-fired power plants of the 19 countries of the G20 (excluding the European Union) and the world. In our assessment, we remain within a set Paris Climate Agreement compatible carbon budget (see section 3).

The paper builds on earlier work carried out by the International Renewable Energy Agency (IRENA) for the German G20 Presidency (IRENA, 2017c; IRENA and IEA, 2017). In section 2, we provide an overview of the various definitions and methodologies related to stranded asset concept. In section 3, we provide details of the background data and methodology used for this analysis. We present our results for power sector stranded assets in section 4 and compare these 
estimates with potential asset stranding in other sectors. We discuss the strengths and weaknesses of our methodology and results in section 5 . In section 6 , we end with recommendations for investors, policy makers and other stakeholders of the power sector how the impacts from potential stranded assets can be minimized while achieving decarbonization goals.

\subsection{Brief review of stranded assets definitions and its magnitude}

The stranded asset concept in the energy context has emerged from the terms "stranded costs" or "stranded investment". These terms refer to "the decline in the value of electricity-generating assets due to restructuring of the industry" (CBO, 1998). Several organizations that work in the energy and climate fields have already examined what stranded assets could mean from their own perspective. We discuss the most commonly applied definitions below:

- The IEA (2013) defines stranded assets as "those investments which have already been made but which, at some time prior to the end of their economic life (as assumed at the investment decision point), are no longer able to earn an economic return because of changes in the market and regulatory environment brought about by climate policy".

- The Carbon Tracker Initiative (n.d.) also use this definition of economic loss, but says the losses are a "result of changes in the market and regulatory environment associated with the transition to a low-carbon economy" (Carbon Tracker Initiative, n.d.).

- The Generation Foundation (2013) defines a stranded asset "as an asset which loses economic value well ahead of its anticipated useful life, whether that is a result of changes in legislation, regulation, market forces, disruptive innovation, societal norms, or environmental shocks". 
- The Smith School of Enterprise and the Environment at the University of Oxford employs a 'meta' definition to encompass these (and other) definitions. It states that "stranded assets are assets that have suffered from unanticipated or premature writedowns, devaluations, or conversion to liabilities" (Caldecott, Howarth and McSharry 2013).

We reviewed 31 of the latest studies that have attempted to quantify the scale of asset stranding in different sectors and geographies (see Table 1). Asset stranding is quantified and defined in various settings and for different climate policy ambitions. Twenty-four studies are global in coverage, while seven are country or region specific. Twelve concern upstream fossil fuel production only, ten concern electricity generation (mainly coal-fired power plants), two look at both upstream production and generation together, two concern agriculture, and four cover the global economy. The studies focusing on the upstream fossil fuel production sector have viewed stranded assets from different angles. Several studies estimated the stranded reserves as a share of the total reserves and quantified the impact of decarbonization on financial assets such as equities and bonds. Others took an aggregate "top-down" approach looking at sector wide revenues. Other studies have deployed "value at risk" methodologies to estimate the potential impact of stranded assets where it determines the probability of a defined loss. The research focus on stranded assets in power sector is growing which is the result of increasing focus on the phase out of coal or limit to its growth ${ }^{2}$ and therefore most studies focus on coal-fired power

\footnotetext{
${ }^{2}$ During the $23^{\text {rd }}$ Conference of PartiesCOP23, Canada and the United Kingdom has launched a new global alliance called "Powering Past Coal Alliance" which is joined by more than 20 partners (DBEIS, 2017). In Austria, Canada, Denmark, France and the United Kingdom have recently announced phase out of their coal-fired power plants (BBC
} 
plants worldwide. This brief review of literature shows that varying scope of technology and sector and the use of a wide range of definitions and methodologies in estimation of stranded assets, indicating that the subject is rather complex.

In view of the complexity of the stranded asset subject, we follow a simplified definition of stranded assets as the remaining book value of fossil fuel-fired power plants substituted before the end of their anticipated technical lifetime and without recovery of any remaining value to stay within the carbon budget limit. This definition emphasizes that electricity generation assets become stranded because of the requirement to reduce fossil fuel use significantly in the coming decades in order to achieve a deeply decarbonized energy system. We choose this definition to limit the required data from publicly available sources since we carry out the analysis at the level of countries and with which fossil fuel types electricity is generated from (see section 3.3).

$<$ INSERT TABLE 1 HERE $>$

3.0 Data and methodology

News, 2016). In China and India, more than 100 construction projects have been stopped (Shearer et al., 2017). In India alone, 13.7 GW of proposed coal-fired power plants were cancelled (CleanTechnica, 2017). Analysis for the European Union shows that more than half of all coal power plants are making losses, and this is to increase to cover nearly all power plants by 2030 as renewables grow. The same study estimates that a complete phase-out of coal by 2030 could reduce utility losses by USD 26 billion (Carbon Tracker Initiative, 2017). Large fossil fuel exporting countries like Saudi Arabia are also implementing policies with the aim to diversify their economies through increased used of renewable energy resources (Demirbas et al., 2016). 
In this section, we first introduce the methodology to estimate the installed electricity generation capacities under three cases based on IRENA's global Renewable Energy Roadmap (REmap) modelling framework and the subsequent carbon budget assumptions. We then describe the methodology to estimate the stranded assets.

\subsection{Estimation of the electricity generation capacity mix using IRENA's REmap approach}

REmap is IRENA's global energy modelling framework. It includes data from national energy plans of 70 countries that are collected from governments for the period until 2030 and 2050 provided forecasts are available. These countries represent $90 \%$ of total global final energy demand (IRENA, 2017b). REmap also includes a unique technology and cost dataset collected internally by IRENA from real-life projects worldwide (IRENA, 2016a;c). The modelling approach involves a techno-economic assessment of the energy system developments for the energy transformation (power and district heat) and end-use (residential, commercial and public buildings, manufacturing industry and transport) sectors. Kempener et al. (2015) and Saygin et al. (2015) provide further details of the REmap methodology, discuss its strengths and limitations and compare its findings with other widely used global energy scenario models. Applications of the REmap methodology to the energy sector of various countries (see Sgouridis et al., 2016 for the United Arab Emirates, Collins et al., 2018 for the European Union) and comparisons of its results with more complex and dedicated energy models have yielded key insights (see Kempener et al., 2015 for comparison with the national IEA-ETSAP models) where the methodology is found suitable for engaging experts and policy makers in the assessment and 
comparison of renewable energy options and targets across countries, and when complemented with dedicated energy models, it can contribute to national planning and policy assessments.

For this analysis, we narrowed down the geographical scope to 19 countries of the G20 (excluding the European Union), but extended the time scope to 2050 by using the 2030 regional renewable energy roadmap prepared for the G20 as a starting point (IRENA, 2016d;2017d). ${ }^{3}$ G20 countries represent more than three-quarters of the current total installed fossil fuel-based electricity generation capacity and an equal share of the renewable energy deployment potential in the energy sector $(\mathrm{G} 20,2015)$. The world's fastest growing coal power generating countries China, India and Indonesia are part of G20. We regard the geographical scope of our analysis sufficient to draw conclusions for the world since the G20 includes a mix of countries that represent varying level of development and electricity demand growth. This is particularly important since the new built capacity will be subject to the risk of stranded assets in the future that will be needed to supply the demand for new electricity. We assessed each energy carrier in the period between 2015 and 2050 and assumed three cases of energy system development:

- Reference Case: First we developed the baseline which represents the energy demand based on the national energy plan of each country by considering policies in place or under consideration. Based on country plans, we estimate the fossil fuel-based power plant capacity that would be in place for each year covering the $2015-2050$ period. Here, any expected developments in energy efficiency improvement are also accounted for.

\footnotetext{
${ }^{3}$ The 19 countries included in this analysis are: Argentina, Australia, Brazil, Canada, China, France, Germany, India, Indonesia, Italy, Japan, Mexico, Republic of Korea, Russian Federation, Saudi Arabia, South Africa, Turkey, United Kingdom and the United States.
} 
- Delayed Policy Action Case: In a subsequent step, the "Delayed Policy Action" Case is developed which follows Reference Case trends until 2030. After 2030, the deployment of renewables and energy efficiency accelerates enough to ensure that the global energy sector remains within the same carbon budget by 2050 as needed for decarbonization in line with the Paris Climate Agreement (see REmap Case). ${ }^{4}$ This results in stranding a significant amount of the projected fossil fuel-based power plant capacity projected in the Reference Case in 20 years between 2030 and 2050.

- REmap Case: this decarbonization scenario is based on the REmap technology options assessment approach. The REmap Case explores low-carbon technology pathways in all sectors of the energy system to remain within a carbon budget that is defined in line with

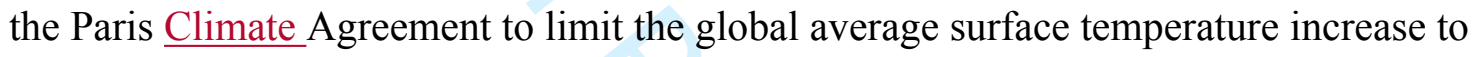
well-below $2^{\circ} \mathrm{C}$ with a $66 \%$ probability (see section 3.2 ). To enable this, we substitute the projected fossil fuel-based capacity with renewable energy.

The REmap Case is the deployment of renewable energy and energy efficiency according to the Reference Case and their additional potential, called the REmap Options. For each country and sector, we identified REmap Options by collecting data from various sources that investigate an

\footnotetext{
${ }^{4}$ Under the Delayed Policy Action Case, the trajectory of emissions follows different pathways for power and other sectors. Until 2030, in all sectors, emissions peak by 2030 following the baseline envisioned by the Reference Case. In the power sector, 2030 onwards, emissions start to decline to reach the level of the REmap Case by 2050. In industry, buildings and transport sectors, emissions decrease to zero by 2050 which is more ambitious than the level in the REmap Case. We make this choice to ensure that the $\mathrm{CO}_{2}$ emissions of the energy sector remains within the carbon budget.
} 
accelerated uptake of renewable energy and energy efficiency technologies. IRENA (2017d) provides the details of the data sources and assumptions employed for the assessment by country and technology. We have given equal priority to all technologies and sectors when identifying the REmap Options without favouring certain technologies or energy applications. Potentials estimates have considered resource availability, access to finance, human-resource needs and supply; manufacturing capacity; policy environment; the age of existing capital stock as well as the future costs of technologies. The addition of each REmap Option substitutes a non-renewable energy technology to deliver the same energy service (e.g. kilowatt-hour of electricity). We assessed the technologies that should be substituted to remain within the carbon budget by primarily focusing on coal. Input was collected from nominated REmap country experts for the part of the assessment that covers the period until 2030 since this is typically based on the policy choices of the countries. The bottom-up country and sectoral analysis is carried out based on the REmap tool that was internally developed by IRENA.

\subsection{Carbon budget}

We identify the REmap Options that are required to put the global energy system on a path in line with the decarbonization goals set out in the Paris Climate Agreement. In this respect, understanding the maximum level of $\mathrm{CO}_{2}$ that can be emitted is essential. There are various ranges provided in the scientific domain depending on the method used, the time span, the probability to meet a specific temperature target, and the non- $\mathrm{CO}_{2}$ emission projections. Peters (2017) compares the relationship between the probability of staying below $2^{\circ} \mathrm{C}$ and what this means for the median temperature increase. According to this comparison, a 50\% probability of staying below $2^{\circ} \mathrm{C}$ means a high risk of exceeding $2^{\circ} \mathrm{C}$ warming. $1.5^{\circ} \mathrm{C}$ median temperature 
requires a $75 \%$ probability of staying below $2{ }^{\circ} \mathrm{C}$ (see also Rockström et al., 2017). For this study, a $66 \%$ probability of staying below $2{ }^{\circ} \mathrm{C}$, without any temporal overshoot has been chosen. This gives a median temperature of $1.6^{\circ} \mathrm{C}$ (IRENA and IEA, 2017).

There is a limit to carbon dioxide emissions that can be emitted in order to remain below $2{ }^{\circ} \mathrm{C}$ with a probability of $66 \%$ above the pre-industrial level. This limit is called the carbon budget. The carbon budget from 2015 till peak warming in the Synthesis Report of the IPCC Fifth Assessment Report (AR5) range between $590 \mathrm{Gt}$ and 1,240 Gt $\mathrm{CO}_{2}$ (Rogelj et al., 2016). ${ }^{5}$ In this analysis, we use a 2015-2100 carbon budget that falls within the average of this range at around $870 \mathrm{Gt}$, reaching zero emissions in 2070 (790 Gt emission budget for 2015-2050). ${ }^{6}$ Assuming a linear reduction in the energy sector $\mathrm{CO}_{2}$ emissions would lead to fossil fuel-related emissions to decline from $32.1 \mathrm{Gt}$ in 2015 to $21 \mathrm{Gt}$ per year in 2030 and $9 \mathrm{Gt}$ in 2050 (IRENA, 2016b; IRENA and IEA, 2017). The carbon budgets assessed by the IPCC's special report on the $1.5^{\circ} \mathrm{C}$ are around $300 \mathrm{Gt} \mathrm{CO}_{2}$ higher than those reported by the AR5 (Rogelj et al., 2018). Compared with the latest carbon budgets provided by the IPCC, our carbon budget assumption corresponds to $1.6^{\circ} \mathrm{C}$ with $50 \%$ probability or $1.7^{\circ} \mathrm{C}$ with $66 \%$ probability. ${ }^{7}$

\footnotetext{
${ }^{5}$ This range refers to the $10^{\text {th }}$ and $90^{\text {th }}$ percentiles to limit global warming to below $2^{\circ} \mathrm{C}$ since $1861-1880$ with more than $66 \%$ probability, and it is calculated from 2016 until year of peak warming.

${ }^{6}$ This includes all sources (i.e. fossil fuel, fugitive, industrial process and clinker, non-energy (e.g. land use change, emissions during the life cycle of chemicals etc.) and emissions from other sources (e.g. waste incineration, fuel fires).

${ }^{7}$ Rogelj et al. (2018) provide a detailed range of carbon budgets that correspond to various levels of additional warming and the respective percentiles of probability for the 2018-2100 period. To place our carbon budget assumption with the range provided by the IPCC, we account for the annual $\mathrm{CO}_{2}$ emissions in 2016 and 2017 


\title{
3.3 Estimation of stranded assets
}

To estimate the value of the stranded power plant assets, we assume that investment costs are recovered linearly over a plant's lifetime, and that the carrying value, at the time of stranding, equals the plant's nominal value minus accelerated depreciation. We make this choice to estimate the stranded assets in a simple and transparent way. There is one limitation to this approach; impairments, which are required in many countries as per accounting standards and occur when the sum of expected future cash flows are less than the carrying value of an asset on the balance sheet, are not considered in the results. Historical impairments would ideally be accounted for, as the value of power plants that are shut down might be below their nominal value minus accumulated depreciation. We made this choice because at a global level there is a lack of disclosure on the carrying value of operational power plants. Estimating carrying values into the future comes with an even larger degree of uncertainty. It would require detailed forecasts of wholesale electricity prices, input prices, technical efficiencies and other factors, on an annual basis, up to 2050 and beyond under various scenarios.

\begin{abstract}
All nuclear generation assets and fossil fuel power plants that need to operate at lower load factors to accommodate a higher penetration of renewables are excluded from this definition. To estimate the plants that need to be shut down before the end of their technical lifetimes, we took the current stock and age distribution of power plants and in a subsequent step we retired by age
\end{abstract}

according to Le Quéré et al. (2018) and the earth system feedback that reduce the carbon budgets reported by Rogelj

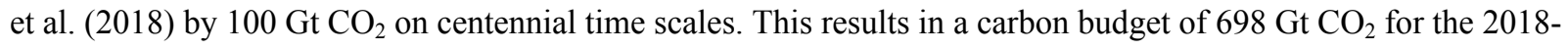
2100 period. 
starting with the oldest first, based on standard assumptions on anticipated technical lifetimes. Similar methodologies have been employed for country-level studies (Burton, 2016) and at a global level by Pfeiffer et al. (2016). ${ }^{8}$

We examine stranded assets in the Delayed Policy Action and REmap cases. This comparison allows us to understand whether the scale of asset stranding will be different if policy action is delayed. To remain within the same carbon budget more investment in renewables and energy efficiency would thus be required after 2030 in the Delayed Policy Action Case. Alternatively, negative emissions technologies could be deployed to compensate for higher emissions, but this is excluded from the analysis.

We carry out the analysis for each year step between 2015 and 2050 . We separately analyse the stranded asset value for the capacity mixes according to REmap and Delayed Policy Action cases by distinguishing power plants fired with coal, gas and oil to generate electricity. Lifetime and capital expenditure data used in the estimation of stranded assets is provided in Table 2 . The analysis comprises the following steps:

(i) Using the age of current stock (or built year of the capacity) and an anticipated technical lifetime, we estimate the existing fossil fuel-based capacity that would be "naturally retired' between 2016 and 2050 .

\footnotetext{
${ }^{8}$ The latter study concludes that "even under the very optimistic assumption that other sectors reduce emissions in line with a $2^{\circ} \mathrm{C}$ target, no new emitting electricity infrastructure can be built after 2017 for this $2^{\circ} \mathrm{C}$ target to be met, unless other electricity infrastructure is retired early or retrofitted with carbon capture technologies." 
(ii) We estimate the capacity that would be stranded, i.e. shut down before the end of its anticipated technical lifetime in three steps:

○ we estimate the new fossil fuel-fired power plants that enter the stock ('new built fossil fuel assets') between 2016 and 2030. 2031 and onwards we assume no additions are made (Kuramochi et al., 2017; Spencer et al., 2018),

- we estimate the power plants that would leave the stock because they reach the end of their lifetime ('natural retirements') and take into account the 'new built fossil fuel assets' in the previous step to derive the 'active capacity' in the absence of any additional climate policy beyond what is envisioned in the Reference Case over the 2015 and 2050 period,

- we estimate the total amount of 'stranded assets' as the difference between the 'required fossil fuel capacity' according to the REmap and Delayed Policy Action cases to remain within the carbon budget and the 'active capacity' estimated in the previous step

(iii)For the capacity that is stranded each year, we estimate its remaining lifetime as a share of the anticipated technical lifetime and multiply this by the plant's capital expenditure (in USD per kilowatt) to estimate the stranded asset value.

(iv)We sum for each of the years the stranded asset value to estimate the total stranded assets per country for the period between 2015 and 2050 (we perform this without discounting).

(v) Finally, we scale the total stranded asset value estimated for the 19 countries by a coverage factor. This factor is estimated based on the total installed fossil fuel-based electricity generation capacity in the 19 G20 countries versus the total installed global capacity in 2015 . 
$<$ INSERT TABLE 2 HERE $>$

\begin{abstract}
4.0 Results
We now present the results of the potential magnitude of asset stranding in the power sector of the G20 countries resulting from energy sector decarbonization. We begin by comparing the scale of asset stranding under both the REmap and the Delayed Policy Action cases in the G20 countries. Subsequently, we look at the value of these stranded assets and how they are geographically distributed across countries and different types of fossil fuel-fired power plants. Where relevant, we scale our findings for the G20 to the global level.
\end{abstract}

\title{
4.1 Stranded assets in the G20 countries
}

Existing power plants are decommissioned as they approach the end of their technical lifetime (natural retirements). Today, the average age of coal-fired power plants ranges from as low as 10-15 years in emerging G20 countries (see Figure 1). The average of gas-fired power plant capacity ranges between 10 and 20 years in most countries explained by the large share of gas capacity installed between 2006 and 2015. Many gas plants that have been built recently reach the end of their lifetimes by around 2030s. By that year, retirements show a peak at around 65 GW/year in the G20 countries (Figure 2). After 2045, there remains no gas-fired power plant that is built before 2015. Coal-fired power plant retirements average $25 \mathrm{GW} /$ year in the entire period. This rate of natural retirement is insufficient to reduce the capacity in operation to the level required in the REmap Case. 
$<$ INSERT FIGURE 1 HERE $>$

$<$ INSERT FIGURE 2 HERE $>$

Figure 3a shows the total active fossil fuel-fired capacity mix between 2015 and 2050 in the G20 countries. In the REmap Case, total global active fossil fuel-fired capacity would decrease from $2,620 \mathrm{GW}$ in 2015 to a total of $684 \mathrm{GW}$ in 2050 . This is equivalent to $5 \%$ of all installed generation capacity that is estimated to be installed in $2050(13,560 \mathrm{GW})$. By comparison, total fossil fuel-fired electricity generation capacity represented around $65 \%$ of the total installed capacity in 2015 worldwide. Renewables would represent the majority share of the remaining $95 \%$ in 2050 with total installed capacity of $12,580 \mathrm{GW}$ (IRENA and IEA, 2017).

We estimate differences in the power plant capacity developments between individual countries (see Appendix A). In G20 countries which are typically characterized by rapid electricity demand growth, such as Argentina, India, Indonesia and Mexico, installed coal-fired power plant capacity is growing significantly according to the Delayed Policy Action Case between 2015 and 2030. In the REmap Case, coal-fired power plant capacity is entirely substituted with renewables by 2050 apart from some minor capacity left in operation in China, India and Indonesia. If the action to deploy renewables is not taken earlier, coal capacity would grow significantly and creates a challenge to strand large amounts of capacity between 2030 and 2050. We estimate a somewhat different trend for gas. Except for Australia, India and the Republic of Korea where gas capacity remains the same between 2015 and 2030, in all other countries capacity grows according to the Delayed Policy Action Case. In the REmap Case some gas capacity is 
substituted with renewables between 2015 and 2050, but the magnitude of substitution is much less than for coal.

Figure $3 \mathrm{~b}$ shows the total capacity of stranded assets by fuel type between 2016 and 2050 in the G20 countries. During this period, at total of $1,914 \mathrm{GW}$ of fossil fuel-fired electricity generation capacity would be stranded under the REmap Case in the G20 countries (1,160 GW coal, 617 GW gas and $137 \mathrm{GW}$ oil). In early years of the period analysed, annual capacity stranding is much higher than in later years. Under the REmap Case, in 2020 more than $60 \mathrm{GW}$ of fossil fuelfired capacity is stranded. It decreases to around $50 \mathrm{GW}$ by 2030 . This is explained by the need to strand many assets in earlier years of the period analysed mix since natural retirements alone would be insufficient to remain in line with the REmap Case capacity mix. More than $80 \%$ of the capacity stranded between 2016 and 2030 is represented by coal. Gas-fired eapacity-power plants represents around $4 \%$ of the total. After 2030, stranded coal-fired power plants-assets level out at around $20 \mathrm{GW}$ per year. ${ }^{9}$ Stranded gas-fired power plants show a growing trend starting in 2043 and peaking by 2048 . This is explained by the significant gas-fired power plant-eapacity $\underline{s}$ stranded in the United States after 2030 since they remain in the energy mix according to its energy plan. In the Delayed Policy Action Case, only a marginal share of fossil fuel-fired electricity generation capacity is stranded until 2030 (5-10 GW/year) because ifff the demand for new fossil fuel-fired capacity. After 2030, capacity stranding average $140 \mathrm{GW}$ per year until 2050 to make sure the capacity mix envisioned by the REmap Case is reached.

\footnotetext{
${ }^{9}$ For stranded coal-fired power plants, there is a temporary drop in years 2031 and 2032, explained by the shift in our approach to estimate the stranded assets before and after 2030.
} 
$<$ INSERT FIGURE 3 HERE $>$

\subsection{Value of stranded assets}

Based on the fossil fuel-fired electricity generation capacitiespower plants that would be stranded in the G20, we estimate cumulative value of stranded assets of up to USD 1,563 billion (bln) in the power sector of the G20 between 2016 and 2050 according to the Delayed Policy Action

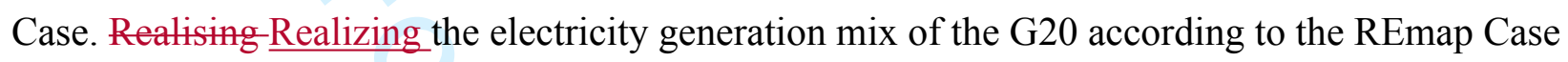
would result in stranded assets estimated at USD 792 bln over the same period. Scaling the G20 findings to the global level, we estimate a total value of stranded assets of USD 1,824 bln according to the Delayed Policy Action Case. By comparison, REmap Case would result in stranded assets of USD 927 bln over the same period, equivalent to half of this total. This translates to savings in total stranded value of USD 946 bln over the 2015-2050 period which is the benefit of early action in implementing more ambitious climate policies (see Table 2).

The value of global stranded assets average USD 54 billion and USD 27 billion per year between 2016 and 2050 according to the Delayed Policy Action and REmap cases, respectively. To put this in perspective, we compare it with today's investment volume in thermal generation assets. According to the IEA estimates, USD 132 billion was spent in fossil fuel-fired power plants in 2017 (IEA, 2018b). The value of stranded assets equals $20-40 \%$ of this amount, indicating their importance in the overall economic impact of energy transition.

We find differences in the country potentials to minimize stranded assets through early action. To discuss these, we categorize countries into three groups: (i) countries where early action 
(REmap Case) results in savings of more than 50\% compared to post-2030 action, (ii) countries where REmap Case results in savings of less than $50 \%$ and (iii) countries where REmap Case results in either no savings or costlier stranded assets. ${ }^{10}$ For the total stranded asset value of all fossil fuel-fired power plants, REmap Case results in savings of more than $50 \%$ in 13 countries of the G20. In Italy and Japan, REmap Case results in savings, but less than 50\%. Delayed Policy Action Case results in lower stranded asset value compared to the REmap Case in China, Saudi Arabia, Turkey and the Republic of Korea. We discuss below the most important findings by country and fossil fuel-type:

(i) Coal-fired power plants: Cumulative stranded coal-fired power plant capacity of China in the 2015-2050 period is around $700 \mathrm{GW}$ in both REmap and Delayed Policy Action cases. However, stranded asset value in the REmap Case China is higher. This is explained by the difference in annual dynamics of stranding and the age profile of assets. Recently built assets are rapidly stranded at $30 \mathrm{GW} / \mathrm{yr}$ under the REmap Case between 2015 and 2030 with an average value of USD 700/kW. Rate of asset stranding continues at $13 \mathrm{GW}$ per year after 2030 and onwards. By comparison, asset stranding starts at low base below $5 \mathrm{GW}$ per year in the Delayed Policy Action Case until 2030. After 2030, asset stranding increases to around $33 \mathrm{GW}$ per year but this happens with a much lower value of USD $350 / \mathrm{kW}$ because these plants have aged in the meanwhile without the need for being stranded. We observe similar trends in Italy, Japan, Republic of Korea and Turkey where REmap Case envisions a significant drop of installed capacity by 2030 thereby requiring assets to be stranded

\footnotetext{
${ }^{10}$ Saving is estimated by dividing the difference between the stranded asset value between Delayed Policy Action Case and REmap Case by the stranded asset value of the Delayed Policy Action Case.
} 
much earlier with a high value. One could expect similar findings for countries such as in India and Indonesia that have similar age profile of the installed coal capacity as China ( $\sim 10$ years old on average). In these countries, total installed coal capacity continues to grow in the REmap Case until 2030 whereas in China there was a significant drop in the same period. As a result, no significant capacity is stranded until 2030. After 2030, installed capacity shows a significant drop due to rapid stranding. Since the annual rate of capacity stranding would be higher under the Delayed Policy Action Case, plants are stranded earlier with a higher value and therefore the stranded asset value in the REmap Case is lower than in the Delayed Policy Action Case in India and in Indonesia

(ii) Gas-fired power plants: As opposed to the case of coal, there are no countries where gas stranding under the REmap Case is higher than in the Delayed Policy Action Case. In Germany, Mexico and South Africa, the total value of stranded gas assets would be equal in both cases as there is no difference in the total installed gas-fired power plant capacity between 2015 and 2050. In most other countries, REmap Case results in stranded asset values that are less than half those in the Delayed Policy Action Case.

(iii) Oil-fired power plants: In the case of oil, the value of stranded assets in the REmap Case is either more expensive or equal to the Delayed Policy Action Case for most countries, so there are no savings. In Argentina, Australia, Brazil, Canada, France, Germany, Indonesia, Italy, Mexico, Russian Federation, Saudi Arabia, Turkey, UK and the US, installed oil capacity is estimated to decline to zero by 2030 in the REmap Case. The value of stranded assets in the REmap Case is higher than in the 
Delayed Policy Action Case for countries with younger capacity stock. There are no differences in the total stranded asset value between the REmap and Delayed Policy Action cases in China, South Africa and Republic of Korea since the required oilfired power plant capacity is the same in both cases.

We estimated the largest savings in stranded asset value in the United States (USD 436 bln) which represents $60 \%$ of G20's total and just below half of the global. India ranks the second by accounting for $20 \%$ of G20's total. More than three-quarters of the early action savings (78\%) would come from coal-fired power plants and the remaining $22 \%$ would be accounted for by gas- and oil-fired power plants.

$<$ INSERT TABLE 3 HERE $>$

We compare the total stranded asset value with the investment needs in the electricity generation capacity according to the REmap Case for the G20 countries (IRENA and IEA, 2017). More capacity for renewable energy would require additional investments under the REmap Case compared to the capacity built under the Reference Case. Total investment needs for renewable energy capacity is estimated at USD 16.6 trillion for the 2015-2050 period (IRENA and IEA, 2017). The value of stranded assets equals $6-12 \%$ of this amount.

Given the crucial role of power plant lifetime choice on our estimates, we carry out a sensitivity analysis to test its impact We initially assumed that the economic lifetime of a power plant equals its technical lifetime. However, this may not be the case since the economic life of a plant 
ends when marginal costs consistently exceed marginal revenues. practice there also exists a grey zone of old plants that are mothballed or where operating hours are reduced significantly compared to new plants. To account for the risk of reaching the end of an economic lifetime, companies might depreciate power plants over shorter periods than their technical lifetimes. The resulting value of stranded assets in the REmap Case is based on when all companies used the lifetimes assumed in this study to depreciate power plants on their balance sheets, and no asset impairments occurred up to the point of stranding. However, given that some companies depreciate power plants over shorter periods of time, or have already witnessed asset impairment in recent years for a variety of reasons, the impact of stranded assets might be more limited. Real data to provide evidence to is unavailable since it refers to company information. However, we use the overview prepared by Farfan and Breyer (2013) about the decommissioning years observed for various types of power plants to show that plants can retire much before than their lifetimes. For instance, gas-fired power plants show decommissioning peaks at years between 4 and 13 (Farfan and Breyer, 2013). By halving the technical lifetime assumptions for all technologies, we estimate $1,575 \mathrm{GW}$ of $2,420 \mathrm{GW}$ of total global stranded assets in the REmap Case have economic value left at the point they are shut down. The remaining $845 \mathrm{GW}$ (about one-third of the total) are plants that are stranded with no remaining economic value, but that still have a remaining technical lifetime. With these assumptions, the stranded asset value reduces by 80\% from USD 927 billion to USD 190 billion (see Figure 4).

$<$ INSERT FIGURE 4 HERE $>$

\subsection{Discussion}


There are several new insights gained from this analysis. By accounting for the capital stock turnover $_{2,}$ the analysis provides, for the first time, the potential of asset stranding in the power sector of the largest economies and in the world if the global energy sector decarbonizes in line with the goals of the Paris Climate Agreement. The analysis also shows the impact of delaying policy action on the value of stranded assets which is typically overlooked. However, the reliability of these findings depends on the robustness of the methodology and the underlying data. While we regard both reliable for a first-order assessment of the stranded assets, they are also subject to uncertainties. In section 5.1, we discuss the strengths and weaknesses of our methodology. In section 5.2, we discuss our results and propose several strategies to reduce the stranded asset value for effective energy, climate and finance policy.

\subsection{Strengths and limitation of our methodology}

In terms of scenario development, we evaluated stranded assets based on a single fossil fuel-fired electricity generation capacity mix according to the REmap Case that was developed by IRENA's REmap methodology (Kempener et al., 2015). While the emphasis for decarbonization would be mainly on coal-fired power plants for most energy scenarios, stranded asset value could change depending on the electricity demand growth and how the mix evolves. For instance, the electricity generation capacity mix of individual countries could change depending on the ambition level to decarbonize the energy sector and the role of low-carbon technologies in end-use sectors within the same country.

The main strength of the methodology we applied here is that the stranded asset analysis can be carried out by using only few parameters: national energy plan and the associated capacity mix, 
required power plant capacity for decarbonization and techno-economic characteristics of the capacity mix such average age, capital costs and lifetime. The analysis can be repeated and updated to estimate the value of stranded assets as new data becomes available and for additional carbon budgets.

We assumed that the investment in fossil fuel-fired power plants cannot be recovered over its lifetime due to reduced demand resulting from energy sector decarbonization policies, thereby estimating the value of stranded assets based on two key components: capital costs and an assumed lifetime of fossil fuel assets. While this brings significant advantages, our simplified approach also has its limitations. Besides capital costs and lifetime, there will be other factors that would play a role in which assets would be stranded such as electricity price dynamics where plant owners can still make profits in a highly decarbonized power system. Estimating these-Their estimation requires an understanding of the investment choices, such as plantspecific discount rates, assumed economic lifetimes, capacity factors, capital, operation, maintenance and energy costs of individual plants. The current value of these parameters is often undisclosed and are proprietary information and given the challenges in projecting their future value creates additional uncertainties. In addition, availability of policies such as capacity markets would help some power plants to continue operating as additional revenues can be generated. HoweverHowever, this may require retrofit investments to enhance the flexibility of such plant. For exampleexample, Danish coal power plants have been retrofitted so they can operate at $10 \%$ of rated capacity. Assessing the impact and availability of such policies would require an in-depth country by country analysis. Accounting for such policy interactions could be important to distinguish which assets are stranded from more stringent energy and climate policy 
and from other factors like energy market developments where fossil fuel prices change or where new reserves are found. Similarly, low-carbon renewable and energy efficient technologies could be developed and deployed without the introduction of climate policies as they become more cost-competitive (IRENA and IEA, 2017). HoweverHowever, we attributed all stranded assets effects to climate policy. We therefore argue that our estimates represent a high end of the stranded asset value related to energy sector decarbonization. The geographical scope of the analysis also plays a role in estimation of the global stranded asset value since our analysis draws conclusions based on the findings of 19 countries that cover around three-quarters of the total installed fossil fuel-based electricity generation capacity. The remaining quarter is represented by around 175 countries of which most are developing with rapid growth in energy demand. The new fossil fuel capacity in these countries will be subject to stranding and therefore a better representation of these countries would help to arrive at more robust estimates.

We compare our findings to those estimates from the IEA which employs a detailed modelling of electricity prices and generation capacities when estimating the value of stranded assets. The methodological focus of the IEA is "... on those assets that may not recoup their capital due to the additional climate policies put in place in the $66 \% 2{ }^{\circ} \mathrm{C}$ Scenario" (IRENA and IEA, 2017). ${ }^{11}$ Total global electricity generation (around 45,000 TWh per year in 2050) and renewable energy share (70\% IEA and $82 \%$ based on IRENA's REmap capacity mix) estimates are similar. The difference in renewable energy shares is explained by more nuclear and fossil fuel capacity with CCS in the IEA generation mix. Based on these, IEA estimates a total global stranded asset value

\footnotetext{
${ }^{11}$ IEA simulates costs and revenues for 87 types of fossil fuel technologies in the world regions of its World Energy Outlook model. A total operational life of 30-40 years has been assumed depending on technology type.
} 
of USD 320 billion for the fossil fuel power plants that would need to be retired before they can recover their investments in capital. These findings are comparable with our estimates when we used shorter lifetimes to estimate the stranded asset value as shown by the results of the sensitivity analysis.

\subsection{Discussion of results: strategies to limit stranded assets}

The results show a significant early action benefit. Delaying energy sector decarbonization becomes technically challenging since large amounts of capacity and related infrastructure must be replaced in a short time. Radical policy interventions would be required that results in high rates of asset stranding. Even in the REmap Case it will be important to develop strategies and deploy technology options to reduce the stranded assets as their value is significant:

(i) Setting more ambitious targets in the power sector: The ambition level of the national energy plans and targets also plays an important role since it determines how much fossil fuel capacity would need to be replaced in the Reference Case by a scenario that remains within the carbon budget. Delaying policy action would be less advantageous from a cost perspective when the ambition level of existing targets and energy plans is raised (-Jakob et al., 2012; Kriegler et al., 2018; den Elzen et al., 2019). This is particularly important for countries with a rapidly growing power sector that face a risk to direct new investment in fossil fuel capacity.

(ii) Deploying zero and negative emission technologies: Nuclear power plants with zero emissions do not affect the carbon budget and their accelerated uptake would be one strategy to reduce stranded assets in the fossil fuel-fired power plant capacity.

Deployment of negative emission technologies would increase the total investment 
needs for low-carbon technologies. These technologies include biomass combustion with carbon capture and storage (BECCS), direct air capture, biochar, soil carbon sequestration, afforestation and reforestation etc (Carbon Brief, 2016). Their deployment as well as more renewable power in combination with CCS could allow more fossil fuel capacity to operate under the REmap Case while remaining within the carbon budget (Johnson et al., 2015). However, most of these technologies are not yet commercially available, and they will come with additional investment needs and risks (Caldecott, Lomax and Workman, 2015; Pfeiffer et al., 2016).

(iii) Converting (partially) fossil fuel-fired power plants to biomass plants: This could be interesting for countries with relatively new coal power plants, where an accelerated stranding path would be costly. Through the conversion of existing plants to use sustainable biofuels, a higher level of emissions reductions can be achieved while avoiding the need for early retirement with significant stranded asset value (Guivarch and Hood, 2011). The benefit of this option needs to be compared on a case by case basis to the alternative of closure of fossil fuel plants and by considering the availability and prices of sustainable and low-carbon biofuels. Commercial scale examples exist such as Drax in the United Kingdom that has been converted from coal to biomass and coal plant with high co-combustion rates in the Netherlands.

(iv) Increasing the ambition level in end-use sectors: Emissions from operating more fossil fuel-fired power plant capacity can be offset if other energy sectors for heating and transport follow a more ambitious low-carbon pathway. Already technology deployment options in these sectors are ambitious in IRENA's REmap analysis and because of the lack of commercially available technology solutions- (IRENA and 
IEA, 2017; Gielen et al. fortheoming2019). ${ }^{12}$ Without increasing the ambition level in the uptake of low-carbon technologies in these sectors, energy sector decarbonization remains unlikely (Oztig, 2017). As for negative emission technologies, development and deployment of solutions require time and come with additional costs. One option is electrification of end-uses coupled with renewable power sooner which can reduce pressure on the scale and pace of required decarbonization in these sectors. Commercializsing and deployment of new emissions reductions measures by 2050 in sectors like heavy industry and freight transport should be accelerated by innovation policies and balancing the climate policy between power and end-use sectors (Gielen, Boshell and Saygin, 2016; Rozenberg, Vogt-Schlib and Hallegatte, 2019).

It is also important to ensure that the difference between "temporary" and "permanent" asset stranding is considered. There is an important distinction to be made between an asset that is devalued due to falling commodity prices and an asset that is closed and no-longer operational. To ensure decarbonization and achieve climate outcomes, it is necessary to permanently close polluting infrastructure not merely temporarily "mothball" assets (Caldecott et al., 2016a). Mothballing comes with the risk that assets might be reused again, for example when the market temporarily improves. Policymakers will likely need to create multifaceted frameworks and mechanisms that result in the permanent closure of such assets in a way that is low cost and address

\footnotetext{
${ }^{12}$ According to the IRENA's analysis, in 2050, there remains about $9.5 \mathrm{Gt}$ of energy sector $\mathrm{CO}_{2}$ emissions under the REmap Case. Around $90 \%$ of all these emissions are from sectors other than power, predominantly from manufacturing industry and transport sector activities. Energy use of residential and commercial buildings could be to large extent decarbonized together with the power sector.
} 
the impacts of asset stranding on government budgets, communities, employment, and financial institutions.

While many strategies can help to reduce the value of stranded assets in the REmap Case, there will be no single solution. An integrated approach will be required that combines setting more ambitious and realistic renewable and other low-carbon energy technology targets for the short term in all sectors of the energy system. To reduce the overall system costs, these efforts will need to be complemented with innovation and R\&D strategies to accelerate low-carbon technology development. This will be particularly important to reduce risks related to technologies with uncertain prospects.

\subsection{Conclusions}

This study presents the first assessment of the stranded asset value in the global power sector between 2015 and 2050 under a decarbonization scenario driven by accelerated renewable energy and energy efficiency. By applying a simplified bottom-up methodology to analyse stranded assets on a country-basis, we estimate that globally more than 2,000 GW fossil fuel-fired electricity generation capacity would be stranded in this period in the REmap Case. The high-end value related to this stranded capacity is estimated at USD 927 billion. If climate policy action to meet the Paris Climate Agreement goals is delayed until 2030, the stranded asset value doubles. Stranded coal assets would represent around three-quarters of the total stranded assets in both cases and China would account for $45 \%$ of stranded assets in the REmap Case. Results depend on assumptions on asset lifetime and the timing of emission reductions objectives. Countries' shortterm actions in relation to their long-term objectives should depend on the age of their assets as 
shown by the example of China. The annual average stranded assets volume between now and 2050 equals $20-40 \%$ of the current annual investment volume in thermal power generation. This comparison suggests that the utility sector may be affected significantly. This highlights the critical role of early action and development of alternative investment strategies that minimise stranded asset risks in the power sector. These findings provide a new aspect of the economics of energy transition and should therefore be accounted for in the design of new energy and climate policies. There are several technology and policy strategies to reduce the value of stranded assets in the power sector while still achieving energy sector decarbonization, for example hydrogen that can substitute natural gas in existing gas pipeline system with limited investment needs or biomass combustion in coal power plant. The trade-offs between these strategies should be assessed in line with the findings of this paper.

The simplified methodology applied provides a first-order estimate of stranded assets, but the analysis needs to be complemented with approaches that consider the electricity price dynamics at plant level. This will also help to separate better stranded assets factors other than climate policy. The findings from this paper provide some clear high-level implications for new energy, climate and technology policies. There will be a need to enhance the understanding of the economic energy sector investment effects of asset stranding such as impact on company valuation, finance and risk mitigation.

\section{Acknowledgements}

We are grateful for the generous support of the Federal Ministry for Economic Affairs and Energy of Germany, which provided financial support to IRENA for conducting this analysis. 
The report has benefited significantly from expert input provided by Jakob Thomae and Christopher Weber ( $2^{\circ}$ Investing Initiative), Julia van Huizen, Carsten Jung, Matthew Scott (Bank of England), Jeremy McDaniels (United Nations Environment Programme Inquiry into the Design of a Sustainable Finance System), Harald Hecking and Theresa Wildgrube (ewi Energy Research \& Scenarios), Marius Backhaus, Martha Ekkert and Martin Schöpe (Federal Ministry for Economic Affairs and Energy of Germany), Laura Cozzi and Timur Gül (International Energy Agency) provided valuable comments to earlier drafts of this manuscript. We are also grateful to the three anonymous reviewers for their useful comments.

The authors declare that there is no conflict of interest regarding the publication of this article.

\section{References}

Ansar, A., Caldecott, B. and Tibury, J. (2013). Stranded assets and the fossil fuel divestment campaign: what does divestment mean for the valuation of fossil fuel assets? Smith School of Enterprise and the Environment, University of Oxford, Oxford. http://www.smithschool.ox.ac.uk/research-programmes/stranded-assets/SAP-divestmentreport-final.pdf.

Bank of England (2015). The impact of climate change on the UK insurance sector. A climate change adaptation report by the prudential regulation authority. Bank of England, London. https://www.bankofengland.co.uk/-/media/boe/files/prudential$\underline{\text { regulation/publication/impact-of-climate-change-on-the-uk-insurance- }}$ sector.pdf?la=en\&hash=EF9FE0FF9AEC940A2BA722324902FFBA49A5A29A. 
BBC News (2016). Canada announces plan to phase out coal by 2030. 21 November. BBC News. http://www.bbc.com/news/world-us-canada-38056587.

Bertram, C., Luderer, C., Pietzcker, R.C., Schmid, E., Kriegler, E. et al. (2015). Complementing carbon prices with technology policies to keep climate targets within reach. Nature Climate Change 5, 235-239.

Burton, J., Caetano, T., Hughes, A., Merven, B., Ahjum, F. et al. (2016). The impact of stranding power assets in South Africa: using a linked model to understand the economy-wide implications. Energy Research Centre, University of Cape Town, Cape Town. www.africaportal.org\%2Fdocuments $\% 2$ F $15384 \% 2$ F 2016 -BurtonetalImpact_stranding_power_sector_assets.pdf.

Caldecott, B. (2011). Why high carbon investment could be the next sub-prime crisis. 12 July, the Guardian. https://www.theguardian.com/environment/2011/jul/12/high-carboninvestment.

Caldecott, B. and Elders, G. (2013). Bloomberg Carbon Risk Valuation Tool. 25 November, Bloomberg New Energy Finance.

https://data.bloomberglp.com/bnef/sites/4/2013/12/BNEF_WP_2013-11-25_Carbon-RiskValuation-Tool.pdf.

Caldecott, B., Howarth, N. and McSharry, P. (2013). Stranded Assets in Agriculture: Protecting Value from Environment-Related Risks. Smith School of Enterprise and the Environment, University of Oxford, Oxford.

https://www.smithschool.ox.ac.uk/publications/reports/stranded-assets-agriculture-reportfinal.pdf. 
Caldecott, B., Tilbury, J. and Ma, Y. (2013). Stranded Down Under? Environment-related factors changing China's demand for coal and what this means for Australian coal assets. Smith School of Enterprise and the Environment, University of Oxford, Oxford. https://ora.ox.ac.uk/objects/uuid:27d52eb8-0c8b-44a6-b395-31c660e32855.

Caldecott, B. and McDaniels, J. (2014). Stranded generation assets: Implications for European capacity mechanisms, energy markets and climate policy. Smith School of Enterprise and the Environment, University of Oxford, Oxford. https://www.smithschool.ox.ac.uk/research/sustainable-finance/publications/StrandedGeneration-Assets.pdf.

Caldecott, B., Lomax, G. and Workman, M. (2015). Stranded carbon assets and negative emission technologies. Smith School of Enterprise and the Environment, University of Oxford, Oxford. https://ora.ox.ac.uk/objects/uuid:258c4d8e-3ea7-4b72-a24e$\underline{44 \mathrm{acd} 01405 \mathrm{~d} 1 / \text { download file?file format }=\text { pdf\&safe filename=2015.02.03 NETs.pdf\&ty }}$ pe_of work=Report.

Caldecott, B., Dericks, G. and Mitchell, J. (2015). Subcritical coal in Australia: Risks to investors and implications for policymakers. Smith School of Enterprise and the Environment, University of Oxford, Oxford. https://www.smithschool.ox.ac.uk/research/sustainable-finance/publications/SubcriticalCoal-in-Australia Investors\&Policymakers.pdf.

Caldecott, B., Harnett, E., Cojoianu, T., Kok, I., Pfeiffer, A. (2016a). Stranded assets: A climate risk challenge. Inter-American Development Bank, Washington, D.C. https://publications.iadb.org/bitstream/handle/11319/7946/Stranded-Assets-A-ClimateRisk-Challenge-Monograph.pdf? sequence=1. 
Caldecott, B., Kruitwagen, L., Dericks, G., Tulloch, D.J., Kok, I. et al. (2016b). Stranded Assets and Thermal Coal: An analysis of environment-related risk exposure. Smith School of Enterprise and the Environment, University of Oxford, Oxford. https://papers.ssrn.com/sol3/papers.cfm?abstract id=2779580.

Caldecott, B., Dericks, G., Tulloch, D.K., Kruitwagen, L., Kok, I. (2016c). Stranded Assets and Thermal Coal in Japan: An Analysis of Environment-Related Risk Exposure. Smith School of Enterprise and the Environment, University of Oxford, Oxford.

Carbon Brief, (2016). “Explainer: 10 Ways 'negative Emissions' Could Slow Climate Change.” Carbon Brief. https://www.carbonbrief.org/explainer-10-ways-negative-emissions-couldslowclimate-change.

Carbon Tracker Initiative (2011). Unburnable Carbon - Are the world's financial markets carrying a carbon bubble? https://www.carbontracker.org/wpcontent/uploads/2014/09/Unburnable-Carbon-Full-rev2-1.pdf

Carbon Tracker Initiative (2013). Unburnable Carbon 2013: Wasted capital and stranded assets. http://www.carbontracker.org/wp-content/uploads/2014/09/Unburnable-Carbon-2-WebVersion.pdf.

Carbon Tracker Initiative (2014a). Carbon supply cost curves: Evaluating financial risk to oil capital expenditures. http://www.carbontracker.org/wp-content/uploads/2014/09/CTI-OilReport-Oil-May-2014-13-05.pdf.

Carbon Tracker Initiative (2014b). Carbon supply cost curves: Evaluating financial risk to coal capital expenditures. http://www.carbontracker.org/wp-content/uploads/2014/09/CTI-Coalreport-Sept-2014-WEB1.pdf. 
Carbon Tracker Initiative (2015a). Carbon supply cost curves: Evaluating financial risk to gas capital expenditures. http://www.carbontracker.org/wp-content/uploads/2015/07/CTI-gasreport-Final-WEB.pdf.

Carbon Tracker Initiative (2015b). Carbon Asset Risk: from rhetoric to action. https://www.carbontracker.org/reports/carbon-asset-risk-from-rhetoric-to-action/.

Carbon Tracker Initiative (2015c). The \$2 trillion stranded assets danger zone: How fossil fuel firms risk destroying investor returns. http://www.carbontracker.org/report/stranded-assetsdanger-zone/.

Carbon Tracker Initiative (2017). Lignite of the living dead. https://www.carbontracker.org/reports/lignite-living-dead/.

Carbon Tracker Initiative (n.d.). Carbon Tracker Initiative's Definition of Stranded Assets. http://www.carbontracker.org/resources/.

Carney, M. (2015). Breaking the Tragedy of the Horizon - climate change and financial stability. 29 September 2015, Lloyd's of London, London. http://www.bankofengland.co.uk/publications/Documents/speeches/2015/speech844.pdf. CBO-Congressional Budget Office (1998). Electric Utilities: Deregulation and Stranded Costs. October 1998. Congressional Budget Office, Washington, D.C. https://www.cbo.gov/sites/default/files/105th-congress-1997-1998/reports/stranded.pdf.

Clean Technica (2017). India cancels nearly 14 gigawatts of proposed coal plants. 25 May 2017. https://cleantechnica.com/2017/05/25/india-cancels-nearly-14-gw-proposed-coal-plants/.

Collins, S., Saygin, D., Deane, J.P., Miketa, A., Gutierrez, L. et al. (2018). Planning the European power sector transformation: The REmap modelling framework and its insights. Energy Strategy Reviews 22, 147-165. 
DBEIS-Department for Business, Energy \& Industrial Strategy (2017). Powering Past Coal Alliance: Declaration. 16 November 2017. UK Government. London. https://www.gov.uk/government/uploads/system/uploads/attachment_data/file/666736/Fina 1_Declaration PPCA 111217.pdf.

Demirbas, A., Kabli, M., Alamoudi, R.H., Ahmad, W., Basahel, A. (2016). Renewable energy resource facilities in the Kingdom of Saudi Arabia: Prospects, social and political challenges. Energy Sources, Part B: Economics, Planning, and Policy 12, 8-16. den Elzen et al. (2019). Are the G20 economies making enough progress to meet their NDC targets? Energy Policy 126, 238-50.

Dietz, S., Bowen, A., Dixon, C., Gradwell, P. (2016). 'Climate value at risk' of global financial assets. Nature Climate Change 6, 676-679.

Edenhofer, O., Knopf, B., Bak, C., Bhattacharya, A. (2017). Aligning climate policy with the finance ministers' G20 agenda. Nature Climate Change 7, 463-465.

Farfan, J. and C. Breyer (2017). Structural changes of global electricity generation capacity towards sustainability and the risk of stranded investments supported by a sustainability indicator. Journal of Cleaner Production 141, 370-384.

Frankfurt School-UNEP Centre (2017). Global Trends in Renewable Energy Investment 2017. Frankfurt School - UNEP Collaborating Centre for Climate \& Sustainable Energy Finance, Paris. http://fs-unepcentre.org/sites/default/files/publications/globaltrendsinrenewableenergyinvestment2017.p df.

G20-Group of Twenty (2017). Annex to G20 Leaders Declaration. G20 Hamburg Climate and Energy Action Plan for Growth. G20 Germany 2017, Hamburg. 


\section{https://www.g20.org/Content/DE/ Anlagen/G7 G20/2017-g20-climate-and-energy-}

en.pdf? blob=publicationFile\&v.

G20 (2015). G20 Toolkit of Voluntary Options for Renewable Energy Deployment. G20 Turkey

2015, Antalya. https://www.irena.org/-/media/Files/IRENA/Agency/Press-

Release/2015/Oct/G20_Toolkit.pdf.

GBPN-Global Buildings Performance Network (2015). Database \& Tools. GBPN, Paris. http://www.gbpn.org/databases-tools.

Generation Foundation (2013). Stranded Carbon Assets: Why and how carbon risks should be incorporated in investments analysis. 30 October. Generation Foundation, London. https://www.genfound.org/media/1374/pdf-generation-foundation-stranded-carbon-assetsv1.pdf.

Gielen, D., Boshell, F. and Saygin, D. (2016). Climate and energy challenges for materials science. Nature Materials 15, 117-120.

Gielen, D., Boshell, F., Saygin, D., Bazilian, M., Wagner, N. et al. The role of renewable energy in the global energy transformation. Manuscript accepted for publication in-Energy Strategy Reviews 24, 38-50.

Griffin, P.A., Jaffe, A.M., Lont, D.H., Dominguez-Faus, R. (2015). Science and the stock market: Investors' recognition of unburnable carbon. Energy Economics 52, Part A, pp. 112.

Guivarch, C. and Hood, C. (2011). "Early retirement of coal-fired generation in the transition to low-carbon electricity systems" in Climate \& Electricity Annual: Data and analyses. OECD/IEA, Paris. 
IEA-International Energy Agency (2013). Redrawing the energy climate map: World Energy Outlook 2013 special report. OECD/IEA, Paris.

IEA (2017). CO2 emissions from fossil fuel combustion 2017. OECD/IEA, Paris.

IEA (2018a). World Energy Outlook 2018. OECD/IEA, Paris.

IEA (2018b). World Energy Investment 2018. OECD/IEA, Paris.

IRENA-International Renewable Energy Agency (2016a). The power to change: Solar and wind cost reduction potential to 2025. IRENA, Abu Dhabi.

http://www.irena.org/DocumentDownloads/Publications/IRENA_Power_to_Change_2016. pdf

IRENA (2016b). REmap: Roadmap for a Renewable Energy Future, 2016 edition. IRENA, Abu Dhabi. http://www.irena.org//media/Files/IRENA/Agency/Publication/2016/IRENA_REmap 2016 edition report.ashx. IRENA (2016c). Technology cost and performance. IRENA, Abu Dhabi. http://www.irena.org//media/Files/IRENA/REmap/Methodology/IRENA_REmap_2030 technology_cost.ashx.

IRENA (2016d). G20 Toolkit for Renewable Energy Deployment: Country Options for Sustainable Growth based on REmap. IRENA, Abu Dhabi. http://www.irena.org//media/Files/IRENA/Agency/Publication/2016/IRENA_REmap_G20 background paper 2016.pdf.

IRENA (2017a). Renewable Capacity Statistics 2017. IRENA, Abu Dhabi. http://www.irena.org/DocumentDownloads/Publications/IRENA_RE_Capacity_Statistics 2017.pdf

IRENA (2017b). REmap - Renewable Energy Roadmaps. IRENA, Abu Dhabi. http://www.irena.org/remap. 
IRENA (2017c). Stranded Assets and Renewables: How the energy transition affects the value of energy reserves, buildings and capital stock. IRENA, Abu Dhabi. http://www.irena.org/publications/2017/Jul/Stranded-Assets-and-Renewables.

IRENA (2017d). Methodology background document: Development of a decarbonization pathway for the global energy system to 2050. A country-by-country analysis for the G20 based on IRENA's REmap and Renewable Energy Benefits programmes. IRENA, Abu Dhabi. http://www.irena.org//media/Files/IRENA/REmap/Methodology/IRENA_REmap_Decarbonization_Pathway_M ethodology_2017.pdf.

IRENA (2018). Renewable capacity statistics 2018. IRENA, Abu Dhabi. https://www.irena.org//media/Files/IRENA/Agency/Publication/2018/Mar/IRENA_RE_Capacity_Statistics_2018 .pdf.

IRENA and IEA (2017). Perspectives for the Energy Transition: Investment needs for a lowcarbon energy system. IRENA and OECD/IEA, Abu Dhabi and Paris. http://www.irena.org/DocumentDownloads/Publications/Perspectives_for the Energy_Tra nsition 2017.pdf.

Jakob, M., Luderer, G., Steckel, J., Tavoni, M., Monjon, S. (2012). Time to act now? Assessing the costs of delaying climate measures and benefits of early action. Climatic Change 114, 79-99.

Johnson, N., Krey, V., McCollum, D.L., Rao, S., Riahi, K. et al. (2015). Stranded on a lowcarbon planet: Implications of climate policy for the phase-out of coal-based power plants. Technological Forecasting \& Social Change 90, 89-102. 
Karakosta, C., Flamos, A. and Forouli, A. (2018). "Identification of climate policy knowledge needs: a stakeholders consultation approach. International Journal of Climate Change Strategies and Management 10, 772-795.

Kempener, R., Assoumou, E., Chiodi, A., Ciorba, U., Gaeta, M. et al. (2015). A Global Renewable Energy Roadmap: Comparing Energy Systems Models with IRENA’s REmap 2030 Project. Lecture Notes in Energy 30, 43-67.

Krause, F., Bach, W. and Koomey, J. (1989). Energy Policy in the Greenhouse. Volume One: From warming fate to warming limit: benchmarks to a global climate convention. El Cerrito, CA: International Project for Sustainable Energy Paths. www.mediafire.com/file/pzwrsyo1j89axzd/Warmingfatetowarminglimitbook.pdf.

Kriegler, E., Bertram, C., Kuramochi, T., Jakob, M., Pehl, M. et al. (2018). Short term policies to keep the door open for Paris climate goals. Environmental Research Letters 13, 074022.

Kuramochi, T. et al. (2017). Ten key short-term sectoral benchmarks to limit warming to $1.5^{\circ} \mathrm{C}$. Climate Policy 18, 287-305.

Le Quéré, C. et al. (2018). Global Carbon Budget 2018. Earth Syst. Sci. Data 10, 2141-94.

Lewis, M. C., Voisin, S., Hazra, S., Mary, S., Walker, R. (2014). Stranded assets, fossilized revenues. Kepler Cheuvreux. https://www.keplercheuvreux.com/pdf/research/EG EG 253208.pdf.

McGlade, C. and Ekins, P. (2015). The geographical distribution of fossil fuels unused when limiting global warming to $2^{\circ} \mathrm{C}$. Nature $517,187-190$.

Mercer (2015). Investing in a time of climate change. Mercer, Paris. https://www.mercer.com/content/dam/mercer/attachments/global/investments/mercerclimate-change-report-2015.pdf. 
Morel, A., Friedman, R., Tulloch, D.J., Caldecott, B. (2016). Stranded assets in palm oil production: A case study of Indonesia. Working paper, July 14. Sustainable Finance Programme, SSEE, University of Oxford, Oxford. https://papers.ssrn.com/sol3/papers.cfm?abstract id=2809562.

Nikas, A., Stavrakas, V., Arsenopoulos, A. Doukas, H., Antosiewicz, M. et al. (2018). Barriers to and consequences of a solar-based energy transition in Greece. Environmental Innovation and Societal Transitions. Article in Press.

NREL-National Renewable Energy Laboratory (2010). Cost and Performance Assumptions for Modeling Electricity Generation Technologies. NREL, Lakewood, CO. http://www.nrel.gov/docs/fy110sti/48595.pdf.

Oil Change International (2016). The Sky’s Limit. Why the Paris climate goals require a managed decline of fossil fuel production. Washington, D.C. http://priceofoil.org/content/uploads/2016/09/OCI the skys limit 2016 FINAL 2.pdf.

Oztig, L.I. (2017). Europe's climate change policies: The Paris Agreement and beyond. Energy Sources, Part B: Economics, Planning, and Policy 12, 917-924.

Peters, G. (2017) 'What does “well below $2^{\circ} \mathrm{C}$ ” mean?'. Klima, 4 May. Centre for International Climate Research, Oslo. https://www.cicero.uio.no/no/posts/klima/well-below-2c.

Pfeiffer, A. Millar, R., Hepburn, C., Beinhocker, E. (2016), The ‘ $2{ }^{\circ} \mathrm{C}$ capital stock' for electricity generation: Committed cumulative carbon emissions from the electricity generation sector and the transition to a green economy, Applied Energy 179, 1395-1408.

Pfeiffer, A. Hepburn, C., Vogt-Schilb, A., Caldecott, B. (2018). Committed emissions from existing and planned power plants and asset stranding required to meet the Paris Agreement. Environmental Research Letters 13, 050419. 
Platts WEPP-World Electric Power Plants Database (2015). World Electric Power Plants Database. https://www.platts.com/products/world-electric-power-plants-database.

Rockström, J., Gaffney, O., Rogelj, J., Meinshausen, M., Nakicenovic, N. et al. (2017). A roadmap for rapid decarbonization. Science 355, 1269-1271.

Rogelj, J., Schaeffer, M., Friedlingstein, P., Gillett, N.P., van Vuuren, D.P. et al. (2016). Differences between carbon budget estimates unravelled. Nature Climate Change 6, 245252.

Rogelj, J. et al. (2018). Mitigation pathways compatible with $1.5^{\circ} \mathrm{C}$ in the context of sustainable development. In: Global Warming of $1.5^{\circ} \mathrm{C}$. An IPCC Special Report on the impacts of global warming $1.5^{\circ} \mathrm{C}$ above pre-industrial levels and related global greenhouse gas emission pathways, in the context of strengthening the global response to the threat of climate change, sustainable development, and efforts to eradicate poverty. In Press.

Rozenberg, J., Vogt-Schlib, A. and Hallegatte, S. (2019). Instrument choice and stranded assets in the transition to clean capital. Journal of Environmental Economics and Management. Article in press.

Saygin, D., Kempener, R., Wagner, N., Ayuso, M., Gielen, D. (2015). The implications for renewable energy innovation of doubling the share of renewables in the global energy mix between 2010 and 2030. Energies 8, 5828-5865.

Sgouridis, S., Abdullah, A., Griffiths, S., Gielen, D., Saygin, D. et al. (2016). RE-mapping the UAE's energy transition: An economy-wide assessment of renewable energy options and their policy implications. Renewable and Sustainable Energy Reviews 55, pp. 1166-1180. Shearer, C., Ghio, N., Myllyvirta, L., Yu, A., Nace, T. (2017). Boom and Bust 2017. Tracking the global coal plant pipeline. March 2017. Coalswarm, Sierra Club and Greenpeace USA 
San Francisco, CA and Washington, DC.

https://www.sierraclub.org/sites/www.sierraclub.org/files/uploadswysiwig/final $\% 20$ boom $\% 20$ and $\% 20$ bust $\% 202017 \% 20 \% 283-27-16 \% 29$.pdf.

Spedding, P., Mehta, K. and Robins, N. (2013). Oil and carbon revisited: Value at risk from 'unburnable' reserves. HSBC Climate Change and HSBC Global Research, London. https://cape.ca/wp-content/uploads/2014/07/2013-HSBC-Unburnable-carbon.pdf.

Spencer, T. et al. (2018). The $1.5^{\circ} \mathrm{C}$ target and coal sector transition: at the limits of societal feasibility. Climate Policy 18, 335-351.

Zhao, X. and Du, D. (2017). Economic costs of aggressive climate policy. Energy Sources, Part B: Economics, Planning and Policy 12, 312-317.

\section{Appendices}

Appendix A. Total installed electricity generation capacities under Delayed Policy Action and REmap cases

$<$ INSERT TABLE A-1 HERE $>$

\section{Appendix B. Estimation of stranded assets outside of the power sector}

In this section, we explain the methodology and data used to estimate stranded assets outside of the power sector, namely in buildings and the upstream fossil fuel sector.

For buildings, we defined stranded asset value as the difference between the cost of retrofitting versus the cost of a near zero energy building (NZEB) (IRENA, 2017c). When estimating the stranded asset value of buildings, we used the following approach: (i) project the floor area of 
buildings for until 2050 (in billion m2), (ii) apply a demolition rate (in \%/yr), (iii) estimate the demolished building area, (iv) estimate the new constructed area as the difference between "projected area" and "demolished area", (v) estimate the share of buildings with zero fossil use between 2016-2020 based on the energy mix of the buildings sector according to the REmap model, since after 2020, we assumed that all new buildings will not use fossil fuels, (vi) estimate the floor area of buildings with " zero fossil use" and with "fossil fuel use". This shows the floor area before any "renovation" is made in the REmap Case, (vii) estimate the specific fossil fuel use of buildings that still use fossil fuel (in GJ/m2). This value decreases in line with renovation that improves energy efficiency and substitutes fossil fuels with renewables, (viii) estimate how much building stock has been renovated by using the difference between specific fossil consumption for two consecutive years, (viiii) multiply the renovated floor area with the typical construction value (in USD/m2) and then multiply with the "deep renovation value" ( $\%$ of the construction value) - "NZEB premium" ( $\%$ of the construction value). This gives the total stranded asset value for buildings. According to the Global Buildings Performance Network (GBPN, 2015), retrofits come with additional costs of around 50\% compared to the construction cost of a new building. By comparison, near zero energy buildings have an additional cost (or premium) of around $25 \%$.

For the upstream fossil fuel sector, we estimated the stranded asset value for both reserves and capital assets (IRENA, 2017c). A three-step approach is followed: (i) estimate an aggregate value of coal-, gas- and oil-producing assets based on the current valuation of major producers, assuming this is based on a Reference Case outlook for demand for coal, gas, and oil, (ii) adjust this by reducing cash flows due to reduced production in the REmap and Delayed Policy Action 
cases, hence, the difference between the adjusted valuation and the current valuation provides an indication of the value of the stranded assets in terms of the oil, gas and coal reserves that are left in the ground as a result of decarbonization policies, and (iii) estimate the capital expenditures that are needed to reach production levels in 2030 as per the Reference Case, and add the difference with the capital expenditures needed in the REmap Case (where lower fossil fuel production levels are needed) as stranded assets in the Delayed Policy Action Case.

We compare our stranded assets estimates for the global power sector with the potential asset stranding in the upstream and building sectors according to IRENA (2017c). When estimating the stranded assets for buildings and upstream sectors, IRENA (2017c) follows a top-down approach compared to the bottom-up methodology we followed here for the power sector. Under the Delayed Policy Action Case, more than USD 10 trillion building assets would be stranded. This could be halved to approximately USD 5 trillion under the REmap Case. The upstream sector assets could be up to USD 7 trillion and USD 3.8 trillion stranded under the Delayed Policy Action and REmap cases, respectively (see Figure 4). The stranded assets represent between $45 \%$ and $85 \%$ of assumed value of today's oil upstream producers which is in line with the earlier findings of the HSBC at 40-60\% (Spedding, Mehta and Robbins, 2013). This comparison shows that asset stranding outside of the power sector could be 4-6 times higher than in the power sector. This highlights the importance of developing policies to address the potential asset stranding outside of the power sector given their magnitude.

$<$ INSERT FIGURE B-1 HERE $>$ 
Table 1: Selected studies on stranded assets reviewed

\begin{tabular}{|c|c|c|c|c|c|c|}
\hline Authors & Year & $\begin{array}{l}\text { Sector and asset } \\
\text { class }\end{array}$ & Coverage & Units of stranded assets & $\begin{array}{l}\text { Definitions / } \\
\text { Methodology / } \\
\text { Assumptions }\end{array}$ & Value of stranded assets \\
\hline $\begin{array}{l}\text { Krause, Bach } \\
\text { and Koomey }\end{array}$ & 1989 & $\begin{array}{l}\text { Fossil fuel } \\
\text { reserves }\end{array}$ & Global & $\begin{array}{l}\text { Unburnable fossil fuel reserve } \\
\text { budget in a } 300 \text { billon ton } \\
\text { carbon world (at the } 1985 \text { mix of } \\
\text { fossil fuels) }\end{array}$ & $\begin{array}{l}\text { Carbon emissions to } \\
\text { limit warming to } \\
0.1^{\circ} \mathrm{C} / \text { decade }\end{array}$ & $\begin{array}{l}\text { Stranded fossil fuel } \\
\text { reserves: } 78 \% \text { coal, } 53 \% \\
\text { gas, } 36 \% \text { oil }\end{array}$ \\
\hline $\begin{array}{l}\text { Caldecott and } \\
\text { Elders }\end{array}$ & 2013 & $\begin{array}{l}\text { Oil and gas } \\
\text { companies } \\
\text { equities }\end{array}$ & Global & $\begin{array}{l}\text { Lost value under various low oil } \\
\text { price or decarbonization } \\
\text { scenarios for various companies }\end{array}$ & $\begin{array}{l}\text { Customizable revenue } \\
\text { model and scenarios } \\
\text { built for Bloomberg }\end{array}$ & $\begin{array}{l}10 \%-90 \% \text { of the share } \\
\text { price }\end{array}$ \\
\hline $\begin{array}{l}\text { Spedding, } \\
\text { Mehta and } \\
\text { Robins }\end{array}$ & 2013 & Oil companies & Europe & $\begin{array}{l}\text { Unburnable oil reserves } \\
\text { estimated with market } \\
\text { capitalization }\end{array}$ & Oil is exposed after coal & $\begin{array}{l}40 \%-60 \% \text { of the equity } \\
\text { valuation }\end{array}$ \\
\hline $\begin{array}{l}\text { International } \\
\text { Energy Agency }\end{array}$ & 2013 & $\begin{array}{l}\text { Power plants and } \\
\text { proven fossil fuel } \\
\text { reserves }\end{array}$ & Global & $\begin{array}{l}\text { Fossil fuel power generation } \\
\text { capacity. } \\
\text { Actual invested oil and gas fields } \\
\text { Cal/oil/gas reserves stranded } \\
\text { between the 450ppm Scenario } \\
\text { and the New Policies Scenario }\end{array}$ & $\begin{array}{l}\text { Excludes upgrade costs } \\
\text { or lost revenue beyond } \\
\text { investment recovery for } \\
\text { power plants, } \\
\text { investment value in } \\
\text { fossil fuel extractive } \\
\text { companies, and } \\
\text { exploration sunk costs } \\
\text { of fossil fuel reserves }\end{array}$ & $\begin{array}{l}\text { Stranded fossil fuel } \\
\text { reserves: } 5 \% \text { oil, } 6 \% \text { gas } \\
165 \mathrm{GW} \text { power plant } \\
\text { capacity or } 8 \% \text { of the total } \\
\text { early retired, idled or } \\
\text { CCS-retrofitted fail to fully } \\
\text { recover investments }\end{array}$ \\
\hline $\begin{array}{l}\text { Caldecott, } \\
\text { Howarth and } \\
\text { McSharry }\end{array}$ & 2013 & $\begin{array}{l}\text { Agriculture } \\
\text { (Natural Capital) }\end{array}$ & Global & $\begin{array}{l}\text { Value at Risk ( } 0.5 \% \text { chance of } \\
\text { occurring) }\end{array}$ & $\begin{array}{l}\text { Risk factors: Physical } \\
\text { Assets, Natural Assets, } \\
\text { Human Assets, Social } \\
\text { Assets, Financial Assets }\end{array}$ & USD 6.3-11.2 trillion \\
\hline $\begin{array}{l}\text { Caldecott, } \\
\text { Tilbury and Ma }\end{array}$ & 2013 & $\begin{array}{l}\text { Coal mining and } \\
\text { processing assets }\end{array}$ & Australia & $\begin{array}{l}\text { Cost of expected capex in new } \\
\text { coal mines }\end{array}$ & - & >AUD 50 billion \\
\hline $\begin{array}{l}\text { Ansar, Caldecott } \\
\text { and Tilbury }\end{array}$ & 2013 & $\begin{array}{l}\text { Oil and gas } \\
\text { companies equity } \\
\text { and debt }\end{array}$ & Global & $\begin{array}{l}\text { Upper limit of possibly equity } \\
\text { divestment and debt }\end{array}$ & $\begin{array}{l}\text { Direct impact from } \\
\text { divestment }\end{array}$ & $\begin{array}{l}\text { Equity divestment for oil } \\
\text { and gas companies: USD } \\
240-U S D 600 \text { billion } \\
\text { Debt: USD } 120 \text { - USD } \\
300 \text { billion }\end{array}$ \\
\hline
\end{tabular}

47

URL: http://mc.manuscriptcentral.com/uesb Email: UESB-peerreview@journals.tandf.co.uk 


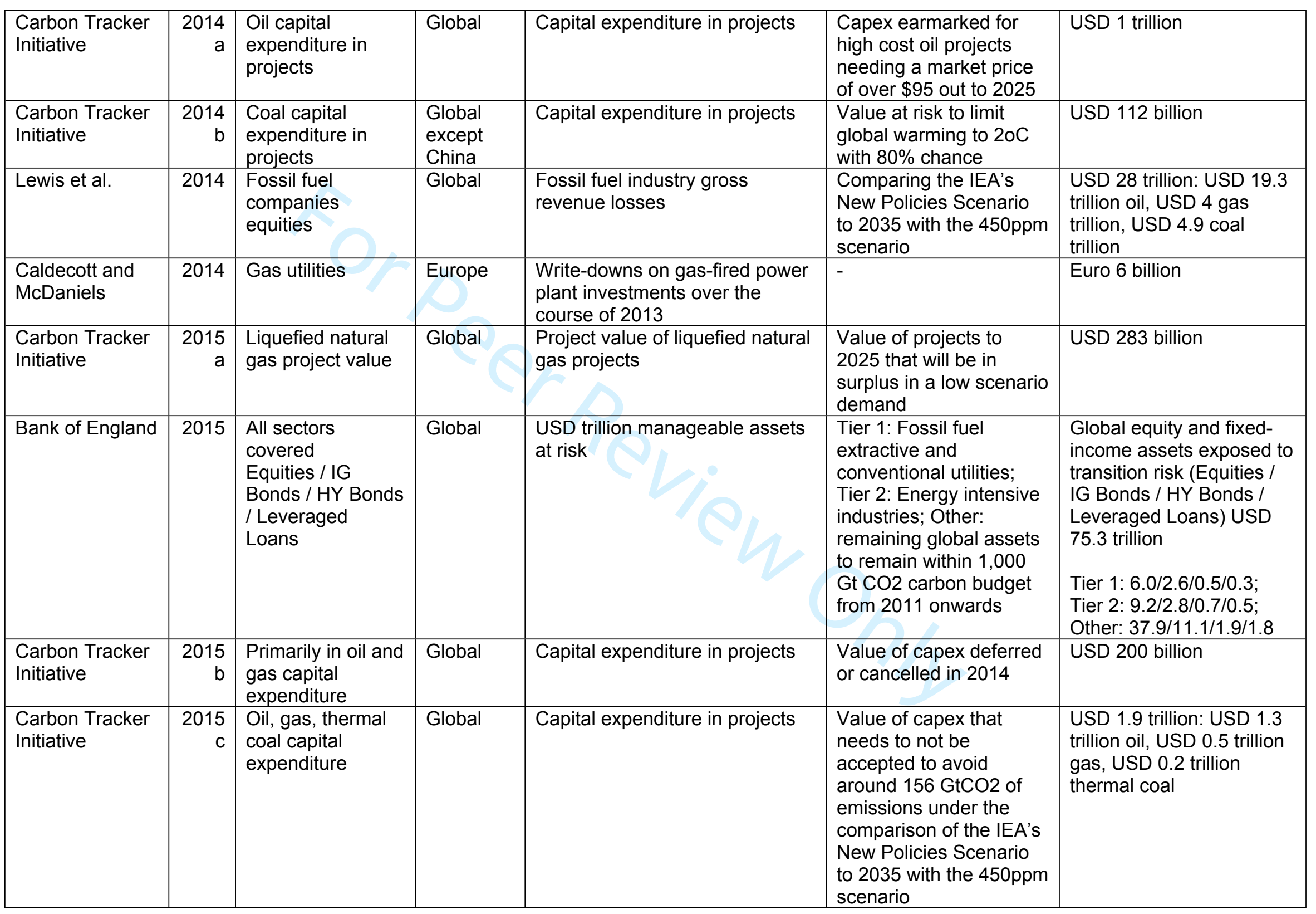




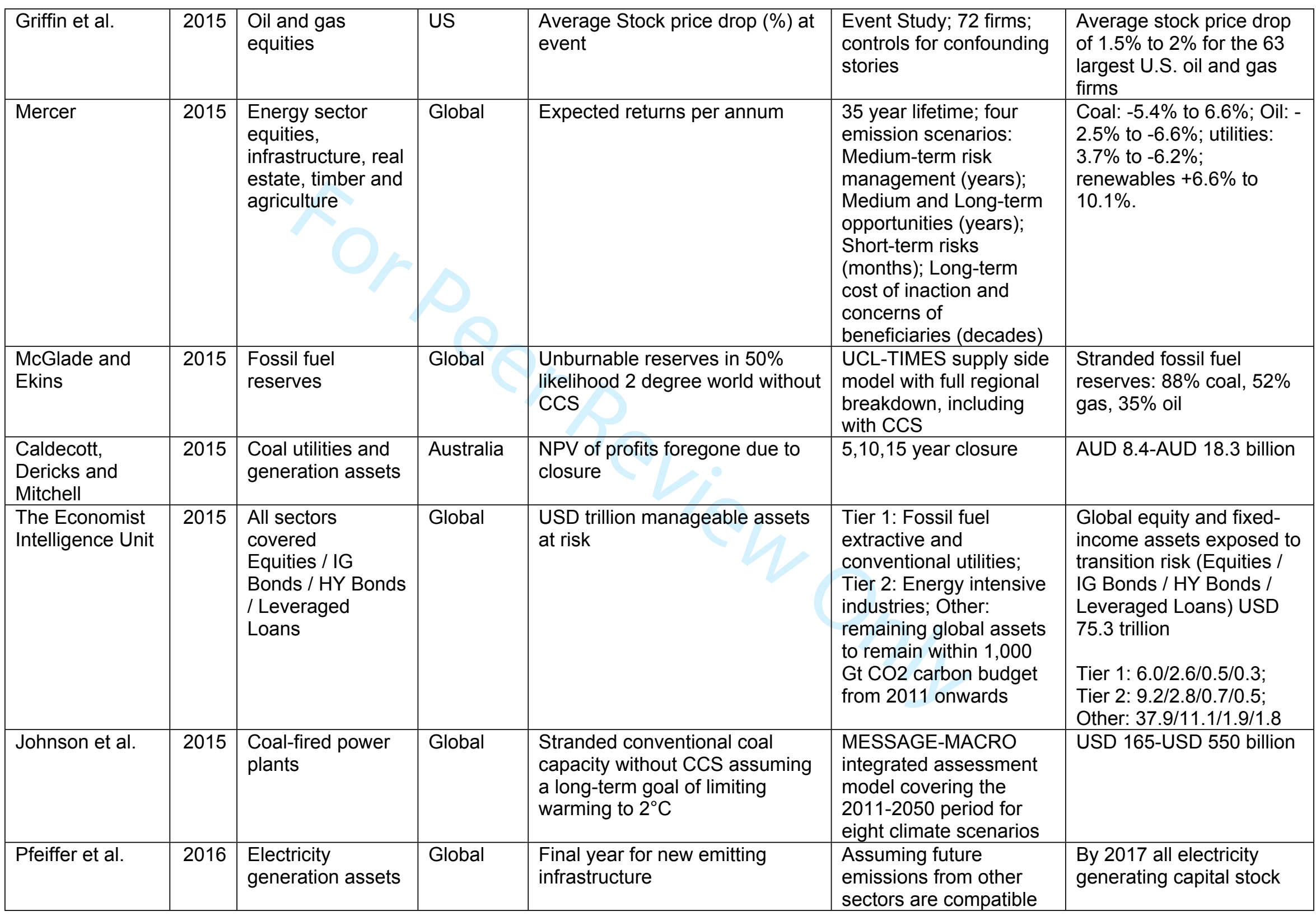




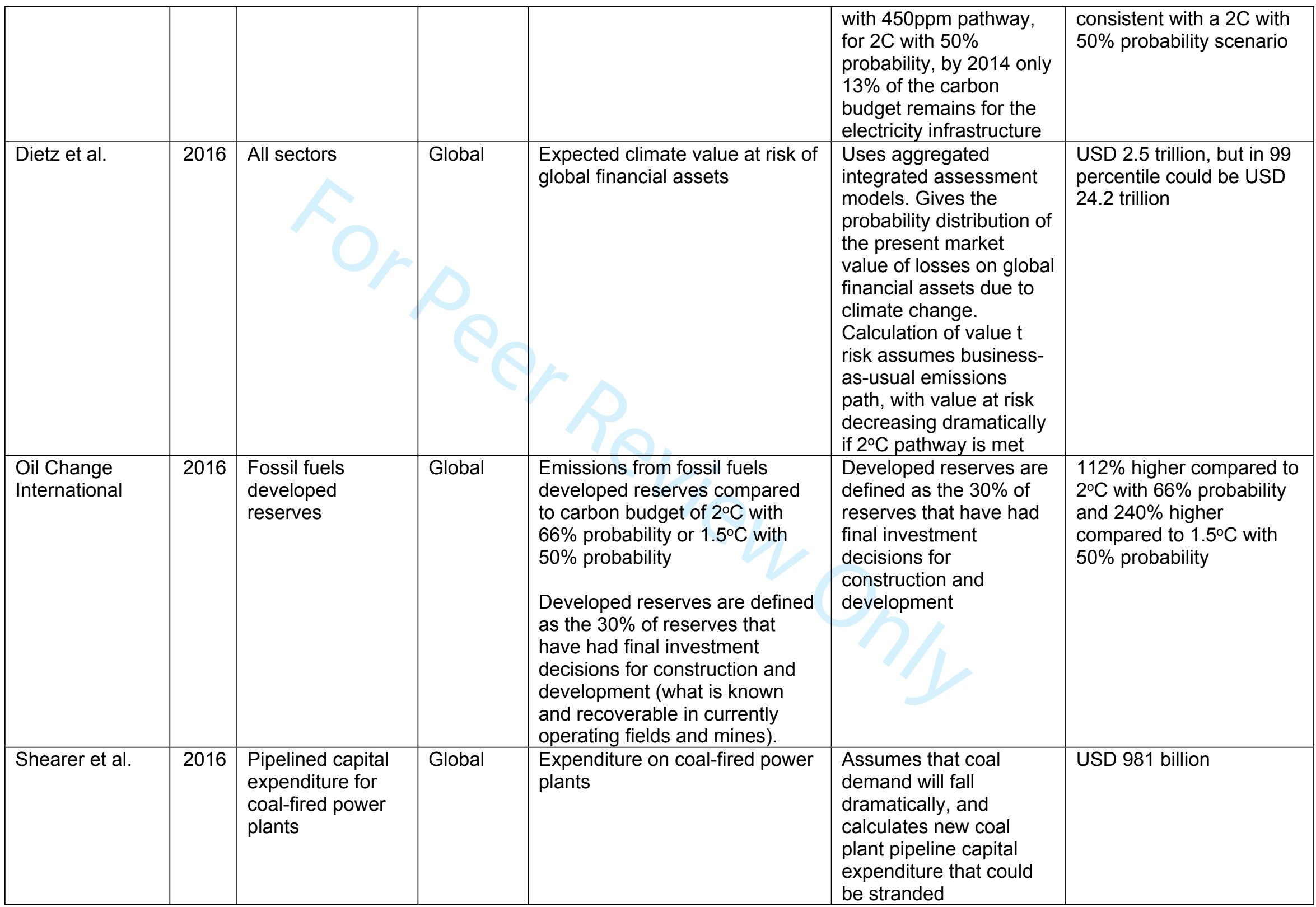




\begin{tabular}{|c|c|c|c|c|c|c|}
\hline Caldecott et al. & $\begin{array}{r}2016 \\
b\end{array}$ & $\begin{array}{l}\text { Coal utilities, } \\
\text { mining and } \\
\text { processing assets }\end{array}$ & Global & $\begin{array}{l}\text { Traffic light exposure to national } \\
\text { and local risk hypotheses }\end{array}$ & $\begin{array}{l}\text { Examines: carbon } \\
\text { intensity, plant age, air } \\
\text { pollution, water stress, } \\
\text { coal quality, heat stress, } \\
\text { electricity demand, } \\
\text { 'utility death spiral', } \\
\text { renewable resources, } \\
\text { renewable policies, } \\
\text { renewables generation } \\
\text { outlook, gas resources, } \\
\text { gas generation, } \\
\text { utilization rates, ccs } \\
\text { legal environment }\end{array}$ & Varying \\
\hline Caldecott et al. & $\begin{array}{r}2016 \\
C\end{array}$ & $\begin{array}{l}\text { Coal-fired power } \\
\text { plants }\end{array}$ & Japan & $\begin{array}{l}\text { Stranded asset value of coal- } \\
\text { fired power plants }\end{array}$ & $\begin{array}{l}\text { Average cost of build; } \\
5,10 \text { and } 15 \text {-year } \\
\text { scenarios; useful life of } \\
40 \text { years; straight-line } \\
\text { depreciation }\end{array}$ & $\begin{array}{l}\text { USD 61.6-USD } 80.2 \\
\text { billion }(23-29 \% \text { of market } \\
\text { capital) }\end{array}$ \\
\hline Morel et al. & 2016 & $\begin{array}{l}\text { Physical and } \\
\text { economic risks of } \\
\text { palm oil } \\
\text { production }\end{array}$ & $\begin{array}{l}\text { Indonesia } \\
\text { and } \\
\text { Malaysia }\end{array}$ & $\begin{array}{l}\text { Traffic light exposure to physical } \\
\text { and economic risks }\end{array}$ & $\begin{array}{l}\text { Risk factors: Land } \\
\text { degradation, Fire and air } \\
\text { pollution, Weather } \\
\text { variability, Greenhouse } \\
\text { gas Regulations, } \\
\text { Emergent Biofuel } \\
\text { Policies, Land use } \\
\text { policy, Reputational } \\
\text { risks }\end{array}$ & Varying \\
\hline $\begin{array}{l}\text { Farfan and } \\
\text { Breyer }\end{array}$ & 2017 & $\begin{array}{l}\text { Fossil fuel-fired } \\
\text { power plants }\end{array}$ & Global & $\begin{array}{l}\text { Fossil fuel-fired power plant } \\
\text { capacity in operation and } \\
\text { commissioned that are in risk of } \\
\text { being stranded }\end{array}$ & $\begin{array}{l}\text { Assessment of capacity } \\
\text { plant by plant }\end{array}$ & $\begin{array}{l}297 \text { GW coal-fired } \\
\text { capacity commissioned } \\
\text { between } 2011 \text { and } 2014 \\
\text { and gas and oil fired } \\
\text { plants commissioned in } \\
2016 \text { and onwards }\end{array}$ \\
\hline Pfeiffer et al. & 2018 & $\begin{array}{l}\text { Coal-fired power } \\
\text { plants }\end{array}$ & Global & $\begin{array}{l}\text { Share of coal-fired power plants } \\
\text { in operation and in planning } \\
\text { stage that can be utilized in } \\
\text { meeting the } 1.5^{\circ} \mathrm{C} \text { and } 2^{\circ} \mathrm{C} \\
\text { global warming goals }\end{array}$ & $\begin{array}{l}\text { Calculation of historic } \\
\text { and current committed } \\
\text { emissions from currently } \\
\text { operating, planned and } \\
\text { already retired power } \\
\text { generators. }\end{array}$ & $\begin{array}{l}51-58 \% \text { of all power } \\
\text { plants that are operating, } \\
\text { planned and under } \\
\text { construction would be } \\
\text { stranded }\end{array}$ \\
\hline
\end{tabular}


Table 2: Data used for estimation of stranded assets in the power sector

\begin{tabular}{|l|l|l|l|}
\hline \multirow{2}{*}{ Technical lifetime } & \multicolumn{2}{|l|}{ Plant capital expenditure } \\
\cline { 3 - 4 } & & OECD & Non-OECD \\
\hline & (years) & $($ USD/kW) & $($ USD/kW) \\
\hline Coal & 50 & 3,000 & 1,300 \\
\hline Gas & 30 & 1,000 & 1,200 \\
\hline Oil & 50 & 1,200 & 1,200 \\
\hline
\end{tabular}

Sources: Farfan and Breyer (2017); IRENA (2016c), NREL (2010)

Notes: The stranded asset value is less than the plant capital expenditure and the difference is higher when the plant is stranded earlier.

The age distribution of existing fossil fuel power capacity stock is based on the Platts WEPP (2015). 
Table 3: Cumulative value of stranded assets between 2016 and 2050 according to the REmap and Delayed Policy Action cases

\begin{tabular}{|c|c|c|c|c|c|c|c|c|c|c|}
\hline \multirow{2}{*}{ in USD bln } & \multicolumn{2}{|l|}{ Coal } & \multicolumn{2}{|l|}{ Gas } & \multicolumn{2}{|l|}{ Oil } & \multicolumn{2}{|l|}{ Total } & \multicolumn{2}{|c|}{ Savings } \\
\hline & REmap & DPA & REmap & DPA & REmap & DPA & REmap & DPA & USD bln & $\%$ \\
\hline Argentina & 0.1 & 1.0 & 1.7 & 6.1 & 0.2 & 2.2 & 2.0 & 9.3 & 7.3 & 78 \\
\hline Australia & 5.5 & 45.1 & 2.7 & 3.0 & 0.4 & 0.2 & 8.6 & 48.3 & 39.7 & 82 \\
\hline Brazil & 1.9 & 3.0 & 2.9 & 9.7 & 4.2 & 5.7 & 9.1 & 18.4 & 12.3 & 67 \\
\hline Canada & 2.5 & 2.7 & 2.7 & 9.1 & 0.2 & 2.4 & 5.4 & 14.3 & 11.5 & 80 \\
\hline China & 416.9 & 263.1 & - & - & 2.0 & 2.0 & 418.9 & 265.1 & -153.7 & -58 \\
\hline France & 0.9 & 5.3 & 1.3 & 2.9 & 0.2 & 0.1 & 2.4 & 5.4 & 4.3 & 80 \\
\hline Germany & 6.4 & 39.4 & 6.3 & 6.3 & 0.1 & 0.8 & 12.8 & 46.4 & 33.6 & 72 \\
\hline India & 44.6 & 199.2 & - & - & 1.1 & 1.9 & 45.6 & 201.1 & 155.4 & 77 \\
\hline Indonesia & 6.1 & 57.6 & - & - & 1.9 & 1.5 & 8.0 & 59.1 & 51.2 & 87 \\
\hline Italy & 3.0 & 2.5 & 7.4 & 9.5 & 0.2 & 2.8 & 10.6 & 14.8 & 4.2 & 28 \\
\hline Japan & 32.3 & 31.0 & 9.0 & 21.4 & 0.8 & 9.6 & 42.1 & 61.9 & 19.8 & 32 \\
\hline Mexico & 6.7 & 10.0 & 10.6 & 19.6 & 1.8 & 1.4 & 19.1 & 31.0 & 11.9 & 38 \\
\hline $\begin{array}{l}\text { Russian } \\
\text { Federation }\end{array}$ & 0.5 & 37.3 & 25.4 & 39.8 & 0.4 & 3.3 & 26.3 & 80.5 & 54.2 & 67 \\
\hline Saudi Arabia & 0.0 & 0.0 & 3.9 & 8.2 & 19.8 & 8.9 & 23.7 & 17.1 & -6.6 & -39 \\
\hline South Africa & 0.6 & 16.7 & 0.8 & 0.8 & 4.3 & 4.3 & 5.6 & 21.8 & 16.1 & 74 \\
\hline $\begin{array}{l}\text { Republic of } \\
\text { Korea }\end{array}$ & 30.8 & 24.2 & 3.4 & 3.5 & 2.9 & 2.9 & 37.1 & 30.5 & -6.6 & -22 \\
\hline Turkey & 18.9 & 13.7 & 3.3 & 4.1 & 0.8 & 0.3 & 23.0 & 18.1 & -4.9 & -27 \\
\hline UK & 8.6 & 8.6 & 2.9 & 13.5 & 0.2 & 0.1 & 11.8 & 22.2 & 13.4 & 60 \\
\hline US & 5.7 & 368.4 & 77.5 & 106.2 & 0.5 & 45.1 & 83.7 & 519.7 & 436 & 84 \\
\hline Global & 670 & 1,348 & 198 & 342 & 59 & 135 & 927 & 1,824 & 935 & 50 \\
\hline
\end{tabular}

DPA: Delayed Policy Action 
Table A-1: Total installed electricity generation capacities under Delayed Policy Action and REmap cases between 2015 and 2050

\begin{tabular}{|c|c|c|c|c|c|c|c|c|c|c|c|c|c|c|}
\hline & \multicolumn{4}{|l|}{ Coal } & \multicolumn{4}{|l|}{ Gas } & \multicolumn{4}{|l|}{ Oil } & \multirow{2}{*}{\multicolumn{2}{|c|}{$\begin{array}{l}\text { Total growth in } \\
\text { electricity generation } \\
{[\% / y r]}\end{array}$}} \\
\hline & \multirow{2}{*}{2015} & \multirow{2}{*}{$\begin{array}{l}\text { DPA } \\
2030\end{array}$} & \multicolumn{2}{|c|}{$\begin{array}{l}\text { REmap } \\
\text { Case }\end{array}$} & \multirow{2}{*}{2015} & \multirow{2}{*}{$\begin{array}{l}\text { DPA } \\
2030\end{array}$} & \multicolumn{2}{|c|}{ REmap Case } & \multirow{2}{*}{2015} & \multirow{2}{*}{$\begin{array}{l}\text { DPA } \\
2030\end{array}$} & \multicolumn{2}{|c|}{$\begin{array}{l}\text { REmap } \\
\text { Case }\end{array}$} & & \\
\hline & & & 2030 & 2050 & & & 2030 & 2050 & & & 2030 & 2050 & $\begin{array}{l}2015- \\
2030 \\
\end{array}$ & $\begin{array}{l}2030- \\
2050 \\
\end{array}$ \\
\hline Argentina & 0 & 1 & 0 & 0 & 11 & 17 & 9 & 0 & 2 & 4 & 0 & 0 & $3.4 \%$ & $0.5 \%$ \\
\hline Australia & 27 & 34 & 14 & 0 & 13 & 14 & 13 & 0 & 2 & 1 & 0 & 0 & $1.6 \%$ & $2.2 \%$ \\
\hline Brazil & 4 & 5 & 0 & 0 & 12 & 26 & 0 & 0 & 10 & 11 & 0 & 0 & $3.8 \%$ & $1.1 \%$ \\
\hline Canada & 9 & 6 & 0 & 0 & 19 & 33 & 0 & 0 & 6 & 5 & 0 & 0 & $0.9 \%$ & $-0.5 \%$ \\
\hline China & 967 & 757 & 377 & 106 & 70 & 150 & 150 & 153 & 9 & 4 & 3 & 0 & $3.3 \%$ & $2.2 \%$ \\
\hline France & 6 & 4 & 0 & 0 & 11 & 14 & 2.5 & 1 & 7 & 1 & 0 & 0 & $-0.1 \%$ & $1.2 \%$ \\
\hline Germany & 51 & 44 & 7 & 0 & 14 & 30 & 30 & 5 & 4 & 2 & 0 & 0 & $0.0 \%$ & $0.3 \%$ \\
\hline India & 185 & 385 & 182 & 44 & 25 & 15 & 15 & 135 & 5 & 6 & 3 & 0 & $6.4 \%$ & $3.4 \%$ \\
\hline Indonesia & 23 & 90 & 26 & 7 & 15 & 48 & 34 & 67 & 9 & 1 & 0 & 0 & $8.1 \%$ & $4.6 \%$ \\
\hline Italy & 11 & 8 & 0 & 0 & 34 & 45 & 31 & 0 & 11 & 6 & 0 & 0 & $1.4 \%$ & $0.5 \%$ \\
\hline Japan & 43 & 46 & 12 & 0 & 54 & 79 & 48 & 2 & 43 & 24 & 8 & 0 & $0.3 \%$ & $-1.1 \%$ \\
\hline Mexico & 6 & 10 & 0 & 0 & 33 & 64 & 30 & 0 & 9 & 2 & 0 & 0 & $4.3 \%$ & $0.9 \%$ \\
\hline $\begin{array}{l}\text { Russian } \\
\text { Federation }\end{array}$ & 50 & 59 & 0 & 0 & 122 & 126 & 97 & 11 & 6 & 6 & 0 & 0 & $1.5 \%$ & $-1.7 \%$ \\
\hline Saudi Arabia & 0 & 0 & 0 & 0 & 33 & 70 & 58 & 26 & 41 & 32 & 0 & 0 & $4.2 \%$ & $2.1 \%$ \\
\hline South Africa & 42 & 44 & 20 & 0 & 4 & 4 & 4 & 1 & 2 & 6 & 6 & 0 & $3.2 \%$ & $0.2 \%$ \\
\hline $\begin{array}{l}\text { Republic of } \\
\text { Korea }\end{array}$ & 27 & 31 & 3 & 0 & 22 & 21 & 21 & 0 & 4 & 6 & 6 & 0 & $1.9 \%$ & $-2.8 \%$ \\
\hline Turkey & 14 & 17 & 0 & 0 & 16 & 22 & 16 & 0 & 2 & 1 & 0 & 0 & $3.0 \%$ & $-0.2 \%$ \\
\hline $\begin{array}{l}\text { United } \\
\text { Kingdom }\end{array}$ & 21 & 1 & 0 & 0 & 36 & 45 & 2 & 0 & 3 & 1 & 0 & 0 & $0.5 \%$ & $2.3 \%$ \\
\hline United States & 277 & 261 & 0 & 0 & 439 & 452 & 360 & 53 & 40 & 65 & 0 & 0 & $0.6 \%$ & $1.1 \%$ \\
\hline Global & 1,924 & 1,866 & 645 & 157 & 1,603 & 2,104 & 1,826 & 1,058 & 443 & 369 & 66 & 0 & $2.4 \%$ & $1.3 \%$ \\
\hline
\end{tabular}

Notes: Values are provided in GW unless otherwize stated. DPA: Delayed Policy Action Case. 
Breakdown of coal capacity by age (bars) Average age of coal capacity (years) (line)

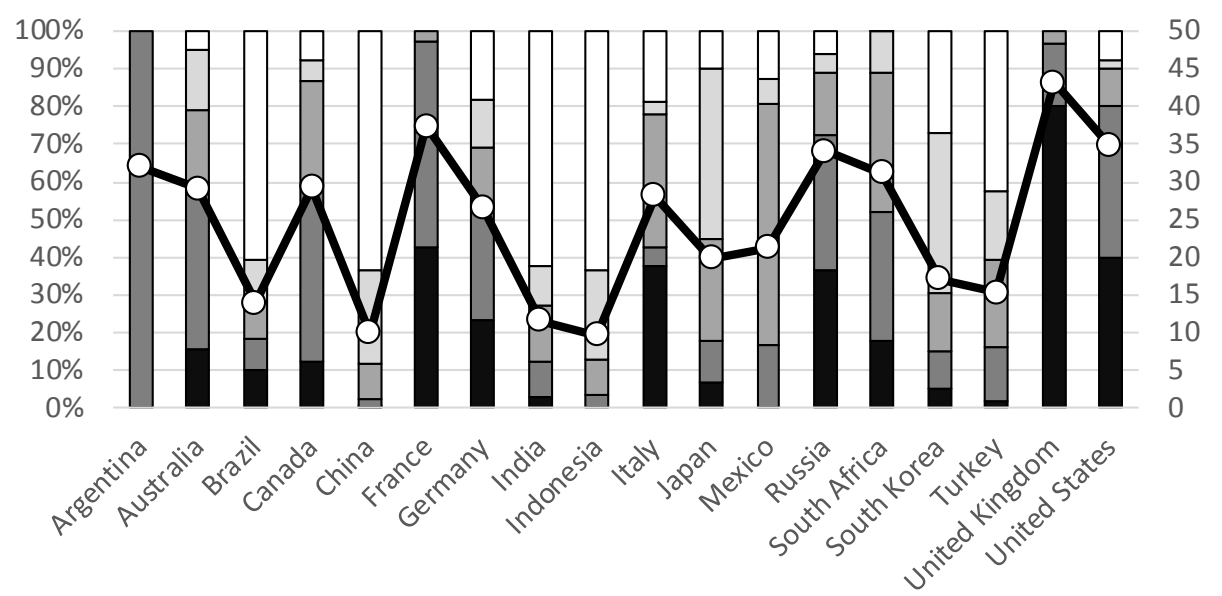

Breakdown of gas capacity by age (bars) Average age of gas capacity (years) (line)
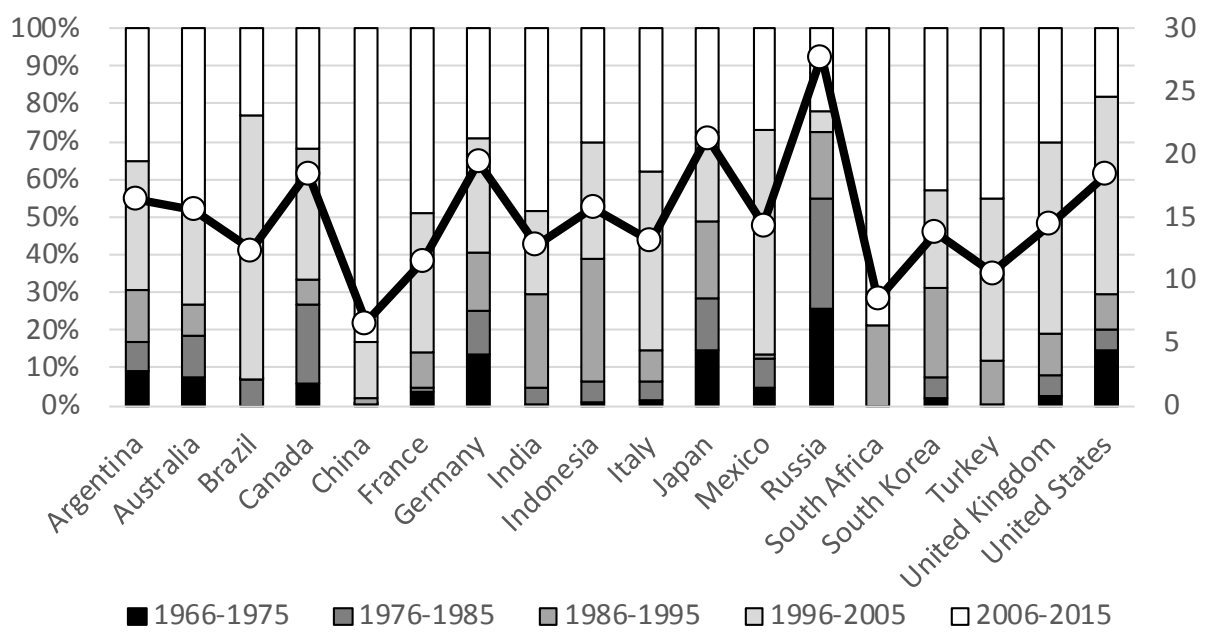

Figure 1: Average age of the installed capacity in the G20 countries

Source: author's analysis based on Platts WEPP (2015). Note: data refers to the status of 2015 


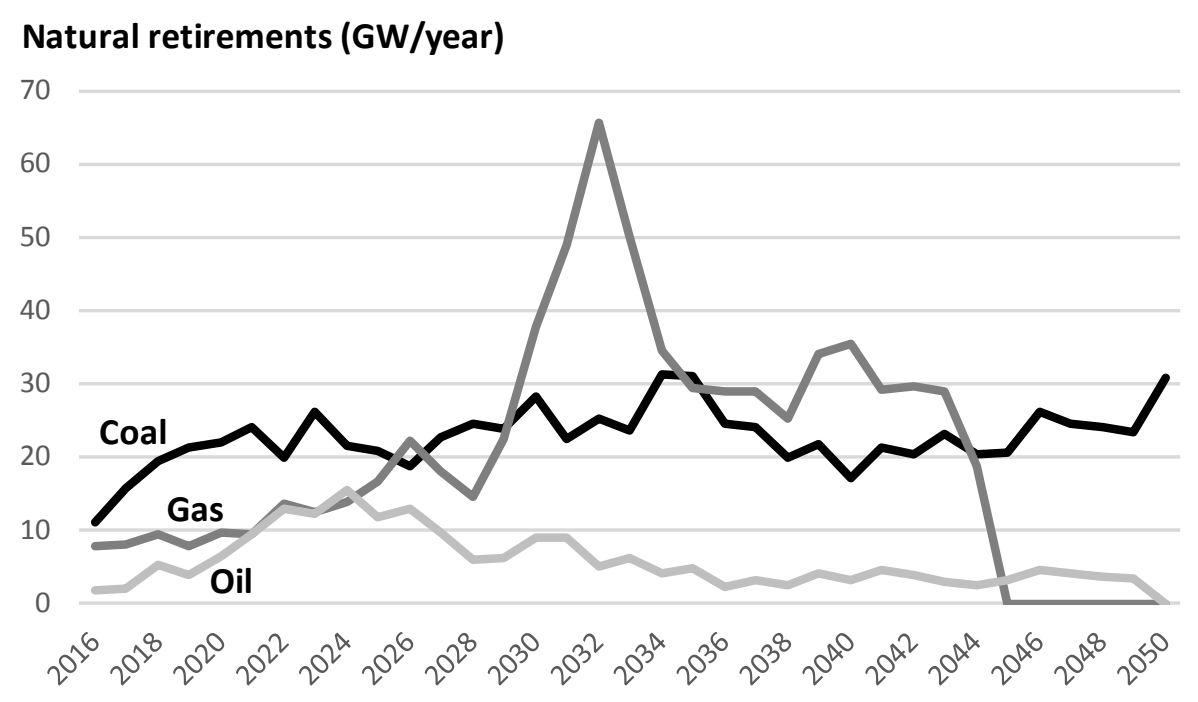

Figure 2: Natural retirements of the existing fossil fuel power plants under the REmap and Delayed Policy Action cases in the G20 countries between 2016 and 2050 

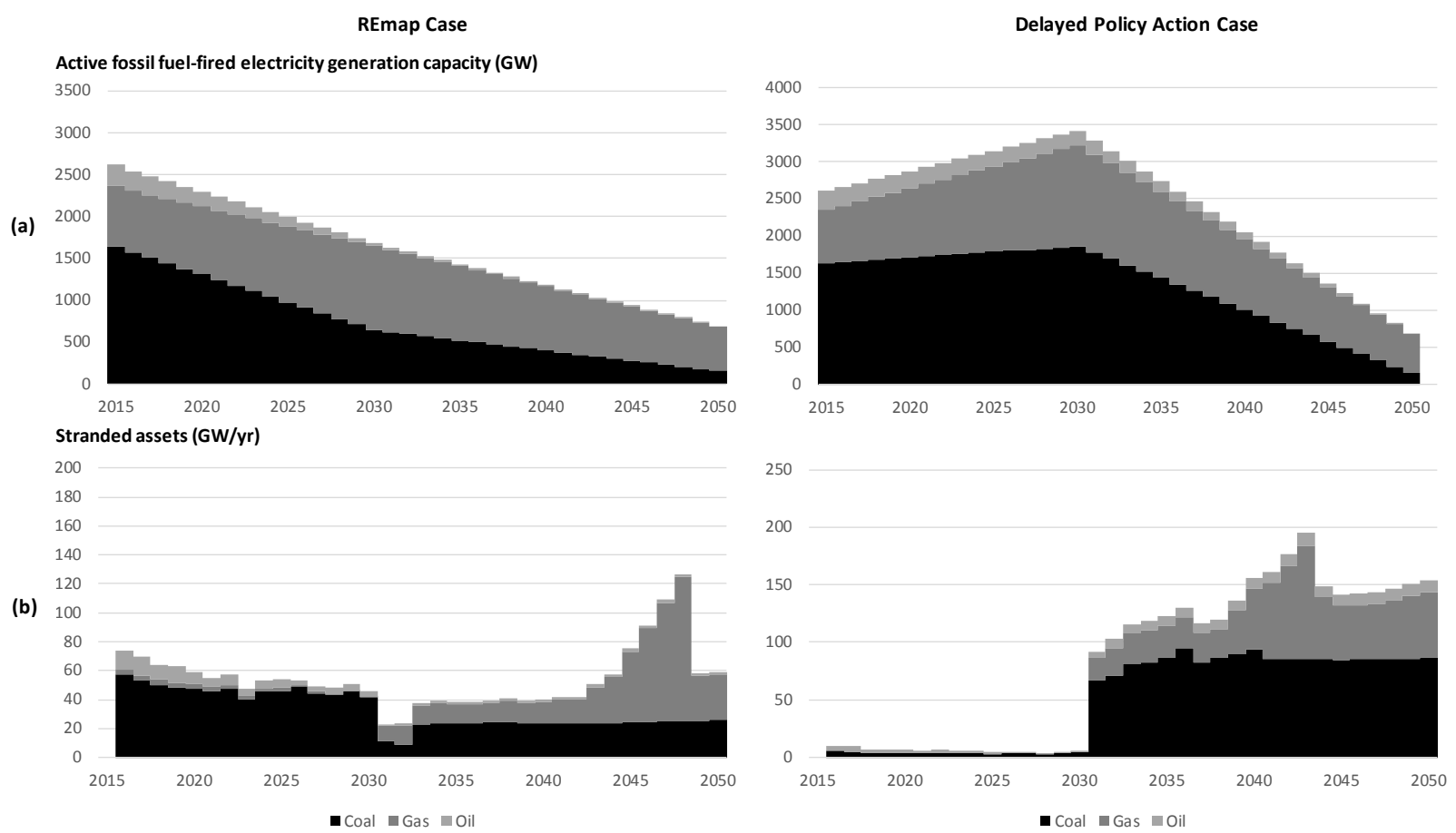

Figure 3: Active capacity (a) and stranded assets (b) in G20 countries between 2015 and 2050 under REmap and Delayed Policy Action cases

Source: for 2015 author's analysis based on Platts data. Note: For 2015, the total installed capacity is higher than the capacity active for some technologies because we disregard all operational capacity that is older than the assumed technical lifetimes. We make this choice given their old age and low efficiency, hence they are mostly mothballed or run limited hours. Even if this capacity is still operating, they are assumed to be fully depreciated already and therefore their shutting down does not impact the stranded assets. This excludes in total about $200 \mathrm{GW}$ coal and $345 \mathrm{GW}$ gas capacity from the G20 countries. 

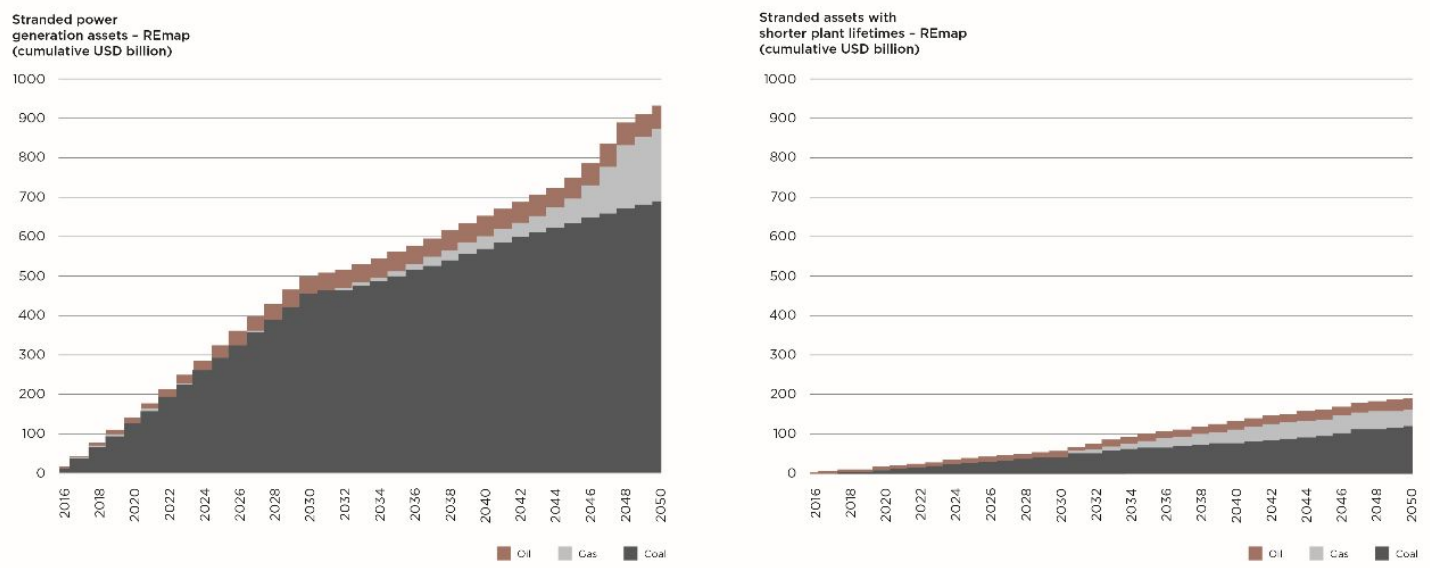

Figure 4: Total global stranded asset value by fuel type under the REmap Case with higher (lefthand side) and shorter (right-hand side) lifetimes between 2016 and 2050 


\section{Stranded assets} (USD bln)

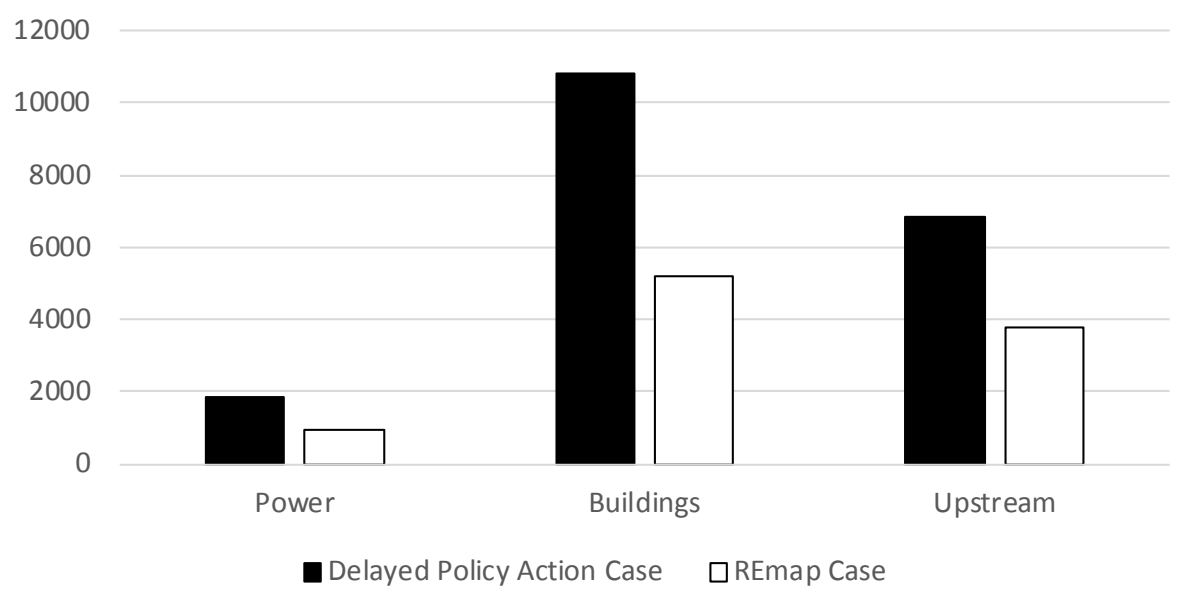

Figure B-1: Comparison of global stranded assets in the power sector with estimates of other sectors between 2015 and 2050

Source: Stranded asset estimates for buildings and upstream sectors are based on IRENA (2017c) 
Figure 1: Average age of the installed capacity in the G20 countries

Figure 2: Natural retirements of the existing fossil fuel power plants under the REmap and Delayed Policy Action cases in the G20 countries between 2016 and 2050

Figure 3: Active capacity (a) and stranded assets (b) in G20 countries between 2015 and 2050 under REmap and Delayed Policy Action cases

Figure 4: Total global stranded asset value by fuel type under the REmap Case with higher (lefthand side) and shorter (right-hand side) lifetimes between 2016 and 2050

Figure B-1: Comparison of global stranded assets in the power sector with estimates of other sectors between 2015 and 2050 